\title{
Geochemistry, alteration, and genesis of gold mineralization in the Okote area, southern Ethiopia
}

\author{
Debele J. DeKSissa ${ }^{1,2}$ and Christian KOEBERL ${ }^{2 *}$ \\ ${ }^{1}$ P.O. Box 28503, Addis Ababa, Ethiopia \\ ${ }^{2}$ Department of Geological Sciences, University of Vienna, Althanstrasse 14, A-1090 Vienna, Austria
}

(Received December 31, 2003; Accepted January 28, 2004)

\begin{abstract}
Ductile shear zone hosted mesothermal gold mineralization of the Okote area is located in southern Ethiopia. Three N$\mathrm{S}$ striking ductile shear zones, with different intensity of shearing and hydrothermal alteration, cut the mafic rocks. The gold-mineralized parts of these shear zones reveal zonings: slightly altered but not sheared protolith at shear boundaries, transitional zone, and mylonite zones. Auriferous quartz-carbonate-tourmaline veins occur mainly in the mylonite zone. The ore minerals of the veins and their wall rocks are pyrite, chalcopyrite, pyrrhotite, gold, and accessory chalcocite, covellite, galena, and melonite $\left(\mathrm{NiTe}_{2}\right)$. The textural relationships among minerals in these alteration zones indicate that epidote, ferroamphiboles, and magnetite were formed first, followed by chlorite, ankerite, pyrrhotite, chalcopyrite I, and $\mathrm{K}$-feldspar, and, finally, calcite, chlorite, biotite, tourmaline, gold, and galena. Primary fluid inclusion data from auriferous type 2 quartz veins $\left(\mathrm{qv}_{2}\right)$ indicate aqueous-carbonic inclusions with low salinity ( $<6.59 \mathrm{wt} \% \mathrm{NaCl}$ equivalent $), 0.38$ to $0.90 \mathrm{~g} / \mathrm{cm}^{3}$ in density that homogenized at $218^{\circ} \mathrm{C}$ to $345^{\circ} \mathrm{C}$. Most of the inclusions decrepitate at $220^{\circ} \mathrm{C}$ to $388^{\circ} \mathrm{C}$ before or immediately after homogenization. Chlorite geothermometry gives temperatures of formation that range from $230^{\circ} \mathrm{C}$ to $410^{\circ} \mathrm{C}$ with modes at $250^{\circ} \mathrm{C}$ and $380^{\circ} \mathrm{C}$, in good agreement with fluid inclusion data. Chemical mass balance studies, using samples from meta-gabbro and alteration products, reveal addition of $\mathrm{K}_{2} \mathrm{O}, \mathrm{P}_{2} \mathrm{O}_{5}$, volatile, $\mathrm{Ba}, \mathrm{Sr}, \mathrm{V}$, and $\mathrm{Cu}$ into wall rock and loss of $\mathrm{MgO}, \mathrm{CaO}$, and $\mathrm{SiO}_{2}$ from the wall rock to the veins accompanying gold mineralization. Chondritenormalized REE patterns of samples show HREE enrichments in meta-gabbro, a flat pattern with a positive Eu anomaly in the epidote-amphibole-magnetite rich transitional zone, and HREE enrichment with a negative Ce anomaly in the mylonite zone. Stable isotope ratios of sulfur, carbon, and oxygen indicate a predominance of deep-seated fluids of metamorphic and magmatic signatures. Considering the combined structural and spatial association of gold with greenschist facies, the mineral- and wall rock chemistry, fluid inclusion data, and isotopic data presented here, we conclude that the Okote gold mineralization formed by interaction of structurally focused hydrothermal fluids with mafic rocks.
\end{abstract}

Keywords: gold mineralization, fluid inclusion, Ethiopia, tourmaline, rare earth element

\section{INTRODUCTION}

A number of placer gold occurrences, as well as the Lega Dembi primary gold mining area, are known to date from the Adola Belt of southern Ethiopia. These gold mineralizations occur in intensely sheared, hydrothermally altered greenschist facies volcano-sedimentary rocks of Megado belt and Kenticha belt. The Okote gold mineralization, the subject of this paper, is one of the areas known by their placer gold deposit in the Megado belt. The study area lies in the southern limit of the Megado belt between $5^{\circ} 4^{\prime}$ to $5^{\circ} 10^{\prime} \mathrm{N}$ and $38^{\circ} 45^{\prime}$ to $38^{\circ} 50^{\prime}$ $\mathrm{E}$ and covers an area of about $115 \mathrm{~km}^{2}$ (Fig. 1).

The Megado belt constitutes the western part of the Adola Belt and is known by the Lega-Dembi primary gold

*Corresponding author (e-mail: christian.koeberl@univie.ac.at) Copyright $\odot 2004$ by The Geochemical Society of Japan. deposit and ubiquitous occurrences of alluvial and primary gold. Except for the Lega-Dembi primary gold deposit, gold exploration performed at Megado belt for the last 30 years failed to locate economic primary gold deposit, mainly due to the complex nature of mineralization and the lack of accurate and precise geochemical, stable isotopic, and fluid inclusion data.

Recent research work on the Lega-Dembi lode-gold deposit (Billay et al., 1997; Mechessa, 1996) reported the occurrences of the gold deposit in a N-S trending, steep westerly dipping shear zones that are associated with quartz-vein system. The ore mineral assemblages consist mainly of chalcopyrite, galena, pyrrhotite, pyrite, and sphalerite, and accessory gersdorffite, arsenopyrite, bournonite, molybdenite, tellurides, silver-tetrahedrite, and gold. The hydrothermal wall rock alteration includes actinolite/tremolite-biotite-calcite-sericite-tourmaline and chlorite-calcite-epidote assemblage. Gold occurs preferentially in the sericite alteration zone (Billay et al., 1997). 


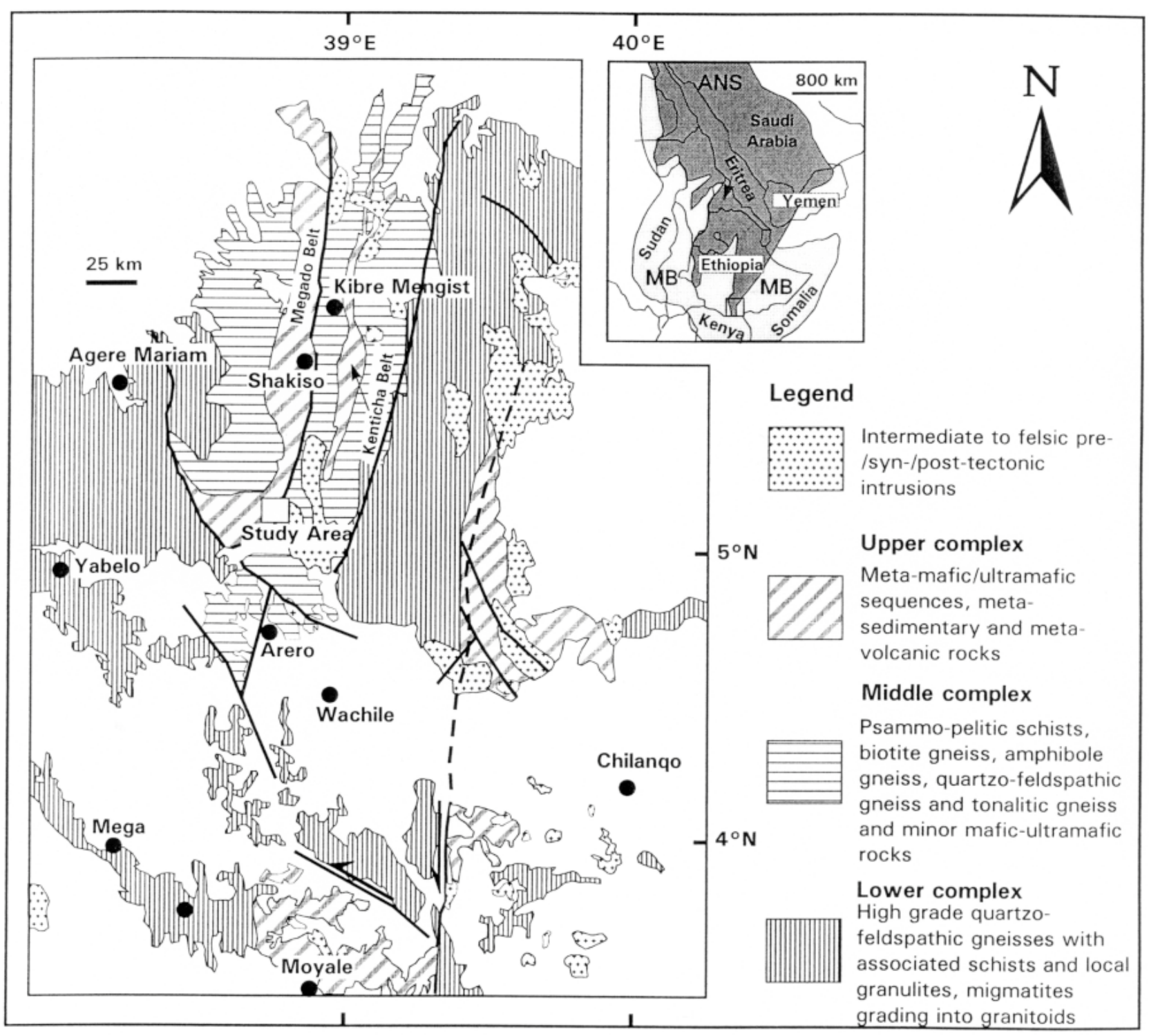

Fig. 1. Location the study area on the geological map of southern Ethiopia. Inset shows the inter-fingering relationship of the Arabian-Nubian Shield (ANS) and the Mozambique Belt (MB) and location of Precambrian rocks of southern Ethiopia (modified from Mohammed, 1999; Kazmin, 1972; Vail, 1987).

$\mathrm{Rb}$-Sr dating of sericite indicates an age of about of 545 Ma for the hydrothermal alteration (Billay et al., 1997). ${ }^{40} \mathrm{Ar} /{ }^{39} \mathrm{Ar}$ dating of biotite and muscovite from ore zone gave an alteration age of about $515 \mathrm{Ma}$ (Mechessa, 1996). Fluid inclusion studies on various quartz-vein generations (Billay et al., 1997; Mechessa, 1996) indicate that the fluids are aqueous-carbonic fluids, low to moderate in salinity, consist of $\mathrm{CO}_{2}, \mathrm{H}_{2} \mathrm{O}, \mathrm{CH}_{4}$, and $\mathrm{N}_{2}$. Homogenization temperatures of the fluids range from 190 to $380^{\circ} \mathrm{C}$.

The Okote area is one of the least studied areas in the Adola Belt. Gold exploration conducted by EIGS (Teferi and Zhbanove, 1991) indicated that the Okote area is geologically favorable for primary gold mineralization. Ex- ploration work by the National Mining Corporation-Dawa Digati Gold Exploration Project (NMC-DDGEP) (Deksissa 1996; Tesfaye et al., 1996, 1997) demonstrated the occurrence of gold-pyrite mineralization in sheared and hydrothermally altered areas. However, the alteration pattern, ore- and gangue mineral assemblage, chemistry and petrography of the host rock, stable isotope studies of ore stage minerals, and physical and chemical characteristics of fluid responsible for gold mineralization were so far unknown.

The purpose of this paper is to report the mineral paragenesis, chemistry of wall rock alteration that associated with gold mineralization, stable isotope data of 
pyrite and ore stage carbonate, fluid inclusion data of auriferous veins, and to discuss the possible genesis of the gold mineralization.

\section{Regional Geology AND METALlogeny}

The geological investigations in east and northeast Africa and Arabia show that zones low-grade metamorphic rocks are common (the Arabian-Nubian shield, ANS), whereas high grade rocks are concentrated further southeastern Africa constituting the Mozambique belt (MB) (Fig. 1). Regional geological, tectonic, and geochemical studies of the ANS suggest rifting at $c a .1200 \mathrm{Ma}$ and subsequent convergence led to the development of intraoceanic arcs and associated marginal basins in the north and narrow basins within the sialic basement gneisses that followed by continent-continent collision and accretion of island arcs (Berhe, 1990).

In the Arabian-Nubian shield the most important metallogenic domains, in terms of frequency and economic importance, are the volcano-sedimentary and plutonic assemblage of the accreted island arc terranes. Volcanogenic base metal sulfides and hydrothermal veinhosted precious metal deposits are abundant in the ANS (Pirajno, 1992 and references therein). The auriferous quartz veins of the ANS are closely associated with greenschist facies rocks and generally confined to highly sheared granitoid rocks and volcano-sedimentary rocks.

The Adola Belt consists of narrow N-S trending, subparallel Megado belt and Kenticha belt (Fig. 1). The rock assemblages of the Megado- and Kenticha belt are ultramafic tectonites, tholeiitic basic volcanic rocks intercalated with meta-sedimentary rocks, and intrusive rocks (Woldehaimanot and Behrmann, 1995; Billay et al., 1997). The two volcano-sedimentary belts are surrounded and separated by gneissic rocks of Middle Complex (Kazmin, 1972) that intercalated with marble. The PanAfrican orogeny in southern Ethiopia is characterized by three major deformational episodes, comprising an earlier fold- and thrust event $\left(D_{1}\right)$, a subsequent event $\left(D_{2}\right)$, which folded and/or reactivated the $\mathrm{D}_{1}$ thrust zones and associated structures, and a final event $\left(\mathrm{D}_{3}\right)$, which produced a set of sinistral strike-slip shear zones, invaded by ubiquitous quartz veins (Worku and Schandelmeier, 1996). The gold mineralization of the Adola Belt occurred over a prolonged deformation history, but closely related to alteration, retrograde greenschist facies assemblage, and brittle-ductile deformation of late $\mathrm{D}_{2}$ and $\mathrm{D}_{3}$ transpressional shear zones (Worku, 1996).

The gold mineralizations in the Adola Belt, similar to gold deposits in the ANS, are strongly associated with the sheared and hydrothermally altered volcano-sedimentary rocks and hosted in quartz veins of variable composition.

\section{SAMPLES AND METHODS}

Representative whole rock samples were collected from unaltered meta-gabbro and zones of different intensities of shearing, hydrothermal alteration, and gold mineralization. Diamond drill holes with inclination of $65^{\circ}$ and azimuth of 110 and 290 were drilled by Geodave mining company using DAME-262 type rig. The lithology, structure, mineralization, quartz veins, and alteration intensity of the rocks have been studied in the field under natural light using high magnification lenses. A number of thin section were prepared and detailed mineralogical, microstructural, and alteration features were studied under normal petrographic microscope. The samples were first crushed in a stainless steel jaw crusher and then powdered in an agate mill for chemical analysis.

\section{Analytical methods}

Twenty-five samples were analyzed for major and minor element oxides and trace elements $(\mathrm{V}, \mathrm{Cr}, \mathrm{Co}, \mathrm{Ni}$, $\mathrm{Cu}, \mathrm{Zn}, \mathrm{Rb}, \mathrm{Sr}, \mathrm{Y}, \mathrm{Nb}$, and $\mathrm{Ba}$ ) using $\mathrm{X}$-ray fluorescence (XRF) spectrometry at the University of the Witwatersrand, Johannesburg, South Africa. Details of the XRF method are described by Reimold et al. (1994). Rareearth elements (REE) and other trace elements (see Table 1) were analyzed using Instrumental Neutron Activation Analysis (INAA) at the University of Vienna, Austria, following procedures described by Koeberl (1993).

Twenty-six samples were analyzed for the contents of elements shown in Table 2 using a Perkin-Elmer Sciex Elan 5000 Inductively Coupled Plasma Mass Spectrometer (ICP-MS) at the Arsenal Laboratory, Vienna, Austria. For the analysis, approximately $100 \mathrm{mg}$ samples were dissolved in high purity acids $(1: 1.5 \mathrm{ml}$ $\mathrm{HNO}_{3}-\mathrm{HClO}_{4}(2.5 \mathrm{ml}$ of each) and $10 \mathrm{ml} \mathrm{HF})$. The solution was evaporated to near-dryness at $120^{\circ} \mathrm{C}$ on a sand

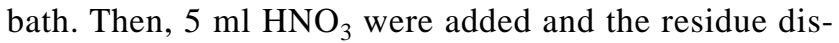
solved and cooled to room temperature. Ultrapure water was added and the contents were transferred into a 100 $\mathrm{ml}$ volumetric flask. Finally, $2 \mathrm{ml}$ of sample solution were taken and diluted with $8 \mathrm{ml}$ ultrapure water. As an internal standard, $200 \mu \mathrm{l}$ of $2 \mu \mathrm{g} / \mathrm{l} \mathrm{Rh}$ solution was used. The precision of the analyses has been calculated based on duplicate analyses and was better than relative $10 \%$ for most of these elements.

The final analytical results shown in Table 1 were obtained by selecting the ICP-MS, XRF, and INAA data (based on the evaluation of the precision of the results from each method for each of the elements).

\section{Mass-balance calculation method}

Hydrothermal alterations associating with ductile shear zones reveal the presence of chemical exchange 
Table 1. Chemical composition of fresh meta-gabbro and hydrothermal alteration products of rocks from the Okote area, southern Ethiopia

\begin{tabular}{|c|c|c|c|c|c|c|c|c|c|c|c|c|c|}
\hline & \multicolumn{6}{|c|}{ Meta-gabbro } & \multicolumn{7}{|c|}{ Chlorite-carbonate-biotite schist } \\
\hline & DR-19 & DR-34 & DR-39 & DR-44 & DR-49 & DR-59 & B8-63 & B8-67 & B8-69 & B8-70 & B9-161 & B10-68 & B11-107 \\
\hline $\mathrm{SiO}_{2}$ & 48.81 & 48.56 & 50.49 & 50.11 & 46.24 & 48.91 & 49.08 & 41.61 & 35.54 & 31.18 & 48.35 & 47.16 & 45.10 \\
\hline $\mathrm{TiO}_{2}$ & 0.2 & 0.35 & 0.37 & 0.41 & 0.28 & 0.31 & 0.59 & 0.65 & 1.04 & 1.13 & 0.44 & 0.37 & 1.20 \\
\hline $\mathrm{Al}_{2} \mathrm{O}_{3}$ & 17.74 & 19.00 & 10.76 & 14.47 & 22.23 & 19.10 & 14.90 & 17.57 & 17.91 & 16.81 & 12.76 & 14.98 & 13.91 \\
\hline $\mathrm{Fe}_{2} \mathrm{O}_{3}$ & 5.77 & 5.41 & 7.64 & 9.47 & 3.23 & 5.29 & 11.12 & 9.89 & 14.1 & 15.01 & 10.73 & 10.12 & 18.55 \\
\hline $\mathrm{MnO}$ & 0.13 & 0.10 & 0.13 & 0.18 & 0.12 & 0.12 & 0.17 & 0.16 & 0.20 & 0.20 & 0.14 & 0.17 & 0.13 \\
\hline $\mathrm{MgO}$ & 8.57 & 7.18 & 14.02 & 10.08 & 5.54 & 8.37 & 4.84 & 6.65 & 7.95 & 9.95 & 5.77 & 6.43 & 7.75 \\
\hline $\mathrm{CaO}$ & 14.89 & 16.63 & 14.94 & 13.14 & 16.15 & 14.63 & 8.56 & 10.16 & 10.94 & 10.07 & 9.38 & 8.97 & 3.71 \\
\hline $\mathrm{Na}_{2} \mathrm{O}$ & 0.90 & 0.80 & 0.0 & 0.95 & 3.75 & 1.60 & 1.00 & 1.68 & 1.05 & 0.43 & 1.28 & 1.65 & 1.16 \\
\hline $\mathrm{K}_{2} \mathrm{O}$ & 0.12 & $<0.01$ & 0.13 & 0.01 & 0.02 & 0.06 & 2.13 & 1.21 & 1.78 & 0.98 & 0.47 & 0.68 & 0.83 \\
\hline $\mathrm{P}_{2} \mathrm{O}_{5}$ & 0.01 & 0.01 & $<0.01$ & 0.01 & $<0.01$ & 0.02 & 0.15 & 0.22 & 0.31 & 0.24 & 0.04 & 0.03 & 0.10 \\
\hline LOI & 1.42 & 1.50 & 1.72 & 1.66 & 1.31 & 1.17 & 7.16 & 9.98 & 9.48 & 14.57 & 9.89 & 9.02 & 7.17 \\
\hline Total & 98.58 & 99.54 & 100.20 & 100.49 & 98.83 & 99.58 & 99.70 & 99.78 & 100.30 & 100.57 & 99.25 & 99.58 & 99.61 \\
\hline $\mathrm{Sc}$ & 35.6 & 43.8 & - & 54.5 & - & - & 31.3 & 25.3 & 48.3 & - & - & 38.3 & 46.2 \\
\hline V & 115 & 134 & 100 & 225 & 99 & 145 & 351 & 287 & 398 & 375 & 309 & 331 & 496 \\
\hline $\mathrm{Cr}$ & 313 & 221 & 5789 & 64 & 26 & 428 & 101 & 195 & 234 & 810 & 66 & 71 & 4.3 \\
\hline Co & 39 & 29 & 226 & 49 & $<9$ & 35 & 35 & 36 & 40 & 53 & 44 & 30 & 57 \\
\hline $\mathrm{Ni}$ & 167 & 57 & 1137 & 87 & $<9$ & 145 & 49 & 106 & 164 & 264 & 55 & 37 & 22 \\
\hline $\mathrm{Cu}$ & 4 & $<2$ & 6 & - & 91 & 13 & 51 & $<2$ & 29 & 22 & 73 & 35 & 109 \\
\hline $\mathrm{Zn}$ & 26 & 35 & 54 & 67 & 41 & 39 & 71 & 105 & 112 & 167 & 77 & 69 & 145 \\
\hline As & 8.36 & 0.44 & - & 6.43 & - & - & $<0.8$ & 0.41 & 0.32 & - & - & 0.30 & 0.80 \\
\hline $\mathrm{Rb}$ & 15 & $<11$ & 5 & 9 & 29 & 12 & 34 & 32 & 44 & 32 & 17 & 10 & 29 \\
\hline $\mathrm{Sr}$ & 105 & 168 & 12 & 75 & 240 & 64 & 274 & 441 & 385 & 233 & 179 & 290 & 101 \\
\hline $\mathrm{Y}$ & 5 & 6 & $<3$ & 10 & 5 & 4 & 12 & 17 & 19 & 20 & 12 & 5 & 17 \\
\hline $\mathrm{Zr}$ & 11 & 19 & 12 & 17 & 56 & 14 & 98 & 212 & 116 & 204 & 29 & 27 & 22 \\
\hline $\mathrm{Nb}$ & 7 & 4 & 5 & 5 & 7 & 5 & 7 & 9 & 9 & 11 & 5 & 6 & 5 \\
\hline $\mathrm{Sb}$ & 2.24 & 0.26 & - & 1.33 & - & - & $<0.1$ & 0.04 & 0.06 & - & - & 0.53 & 0.80 \\
\hline $\mathrm{Ba}$ & 63 & 38 & 39 & 39 & 420 & 68 & 638 & 544 & 1007 & 567 & 105 & 463 & 253 \\
\hline $\mathrm{La}$ & 0.23 & 0.79 & - & 0.23 & - & - & 7.01 & 15.3 & 18.7 & - & - & 1.37 & 2.44 \\
\hline $\mathrm{Ce}$ & $<0.7$ & 2.61 & - & $<0.13$ & - & - & 14.4 & 34.2 & 36.7 & - & - & 2.72 & 4.77 \\
\hline $\mathrm{Nd}$ & $<1.2$ & 7.01 & - & $<3.2$ & - & - & 10.6 & 15.1 & 19.3 & - & - & 1.94 & 2.17 \\
\hline $\mathrm{Sm}$ & 0.34 & 0.63 & - & 0.65 & - & - & 1.67 & 3.80 & 4.17 & - & - & 0.54 & 1.13 \\
\hline $\mathrm{Eu}$ & 0.22 & 0.35 & - & 0.23 & - & - & 0.59 & 1.21 & 1.26 & - & - & 0.24 & 0.53 \\
\hline $\mathrm{Gd}$ & 0.37 & 0.84 & - & 1.44 & - & - & 0.45 & $<2.3$ & 2.86 & - & - & 1.59 & 1.03 \\
\hline $\mathrm{Tb}$ & 0.17 & 0.16 & - & 0.26 & - & - & 0.27 & 0.51 & 0.34 & - & - & 0.14 & 0.38 \\
\hline $\mathrm{Tm}$ & 0.05 & 1.05 & - & 0.21 & - & - & 0.18 & - & 0.23 & - & - & 0.13 & 1.31 \\
\hline $\mathrm{Yb}$ & 0.66 & 1.16 & - & 1.60 & - & - & 0.92 & 2.09 & 1.50 & - & - & 0.45 & 2.20 \\
\hline $\mathrm{Lu}$ & 0.20 & 0.20 & - & 0.22 & - & - & 0.17 & 0.20 & 0.26 & - & - & 0.10 & 0.31 \\
\hline $\mathrm{Hf}$ & 0.02 & 0.26 & - & 0.06 & - & - & 2.08 & 4.68 & 2.28 & - & - & 0.36 & 0.40 \\
\hline $\mathrm{Ta}$ & $<0.1$ & 0.15 & - & 0.45 & - & - & 0.07 & 0.26 & 0.20 & - & - & 0.12 & 0.06 \\
\hline $\mathrm{Au}(\mathrm{ppb})$ & $<14$ & 8 & - & $<4$ & - & - & 25 & 184 & 129 & - & - & 19 & 370 \\
\hline $\mathrm{Pb}$ & 4.9 & - & - & - & - & - & - & - & - & - & - & - & - \\
\hline Th & 0.03 & $<0.2$ & - & 0.05 & - & - & 1.07 & 2.17 & 2.33 & - & - & 0.24 & $<0.3$ \\
\hline $\mathrm{U}$ & $<0.3$ & $<0.6$ & - & $<0.05$ & - & - & 0.33 & 0.56 & 0.73 & - & - & 0.43 & $<0.1$ \\
\hline $\mathrm{Eu} / \mathrm{Eu}^{*}$ & 1.90 & 1.47 & - & 0.73 & - & - & 2.08 & - & 1.11 & - & - & 0.94 & 1.50 \\
\hline$(\mathrm{La} / \mathrm{Yb})_{\mathrm{N}}$ & 0.13 & 0.46 & - & 0.10 & - & - & 5.15 & 4.95 & 8.42 & - & - & 2.06 & 0.75 \\
\hline $\mathrm{K} / \mathrm{Rb}$ & 66 & - & 216 & 9 & 6 & 42 & 520 & 314 & 336 & 254 & 230 & 565 & 238 \\
\hline
\end{tabular}

between fluids and wall rocks. The actual mass gains or losses that took place during these metasomatic alterations cannot be obtained without knowledge of the relationship between composition- and volume changes that accompany the processes. Gresens (1967) suggested incorporating specific gravity data into a two-way mass balance calculation, such that fixing either volume change or the behavior of one component during the reaction provides a unique solution. For any transformation of parent rock to altered product the volume factors $\left(f_{\mathrm{v}}\right)$ have been determined using the following equation (Gresens, 1967), which relates initial (rock A) and final (rock B) compositions:

$$
X_{n}=f_{\mathrm{v}}\left(g^{\mathrm{B}} / g^{\mathrm{A}}\right) C_{n}^{\mathrm{B}}-C_{n}^{\mathrm{A}}
$$

where $X_{n}$ is the actual mass gain or loss of component $n$ producing metasomatic rock $\mathrm{B}$ from the parent $\mathrm{A}$ in wt $\% ; f_{\mathrm{v}}$ is the volume factor, defined as the ratio between the final and initial volume (i.e., $\left.V_{\mathrm{B}} / V_{\mathrm{A}}\right), g^{\mathrm{B}}$ and $g^{\mathrm{A}}$ are the specific gravity of the metasomatic rock and parent rock respectively, and $C_{n}{ }^{\mathrm{A}}$ and $C_{n}{ }^{\mathrm{B}}$ are the weight frac- 
Table 1. (continued)

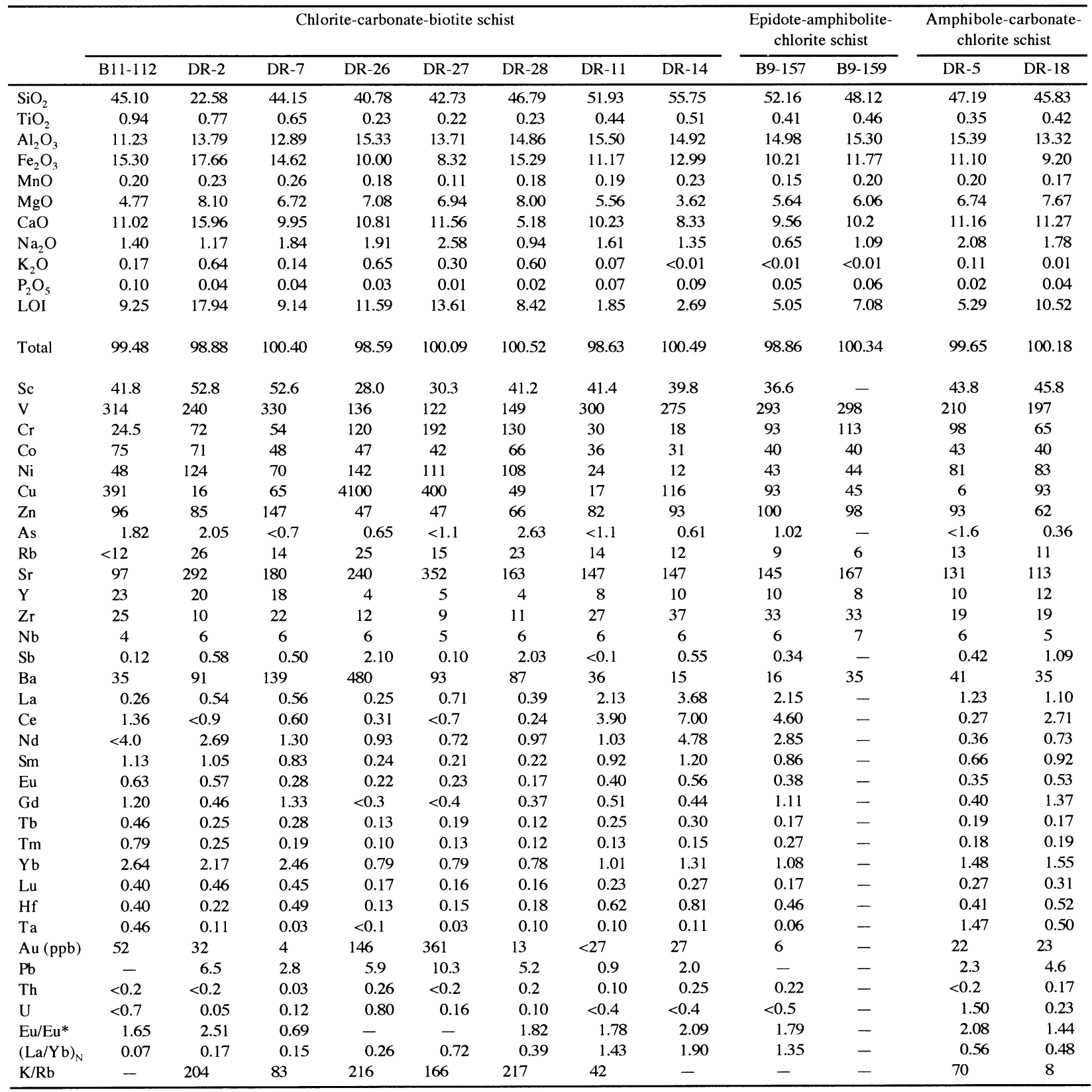

Major element data in wt \%, trace element data in ppm, except as noted. All $\mathrm{Fe}$ as $\mathrm{Fe}_{2} \mathrm{O}_{3}$. - ; not determined.

tion of component $n$ (wt \%) in the parent rock $\mathrm{A}$ and metasomatic rock $\mathrm{B}$ respectively.

In this work, we used the displacement method to determine the specific gravity of parent rock (meta-gabbro) and alteration products on a number of rocks slabs and the results are compared with rocks of similar composition and texture. The chemical data shown in Table 3 have been used to plot the mass gains and losses of the components as a function of the volume factor $\left(f_{\mathrm{v}}\right)$. Since there is no clear clustering of the lines for many elements, the $f_{\mathrm{v}}$ value of least mobile element oxide $\mathrm{Al}_{2} \mathrm{O}_{3}$ in the highly altered rock at $X_{n}=0$ has been used. The volume factor ( $f_{\mathrm{v}}$ value) used to determine mass gained or lost in this work is 1.1 .

\section{Electron microprobe analysis}

Silicate and ore minerals phases from wall rock alteration of auriferous quartz veins were analyzed for major and minor element contents using a CAMECA SX 100 electron microprobe at the Institute of Petrology, Univer- 


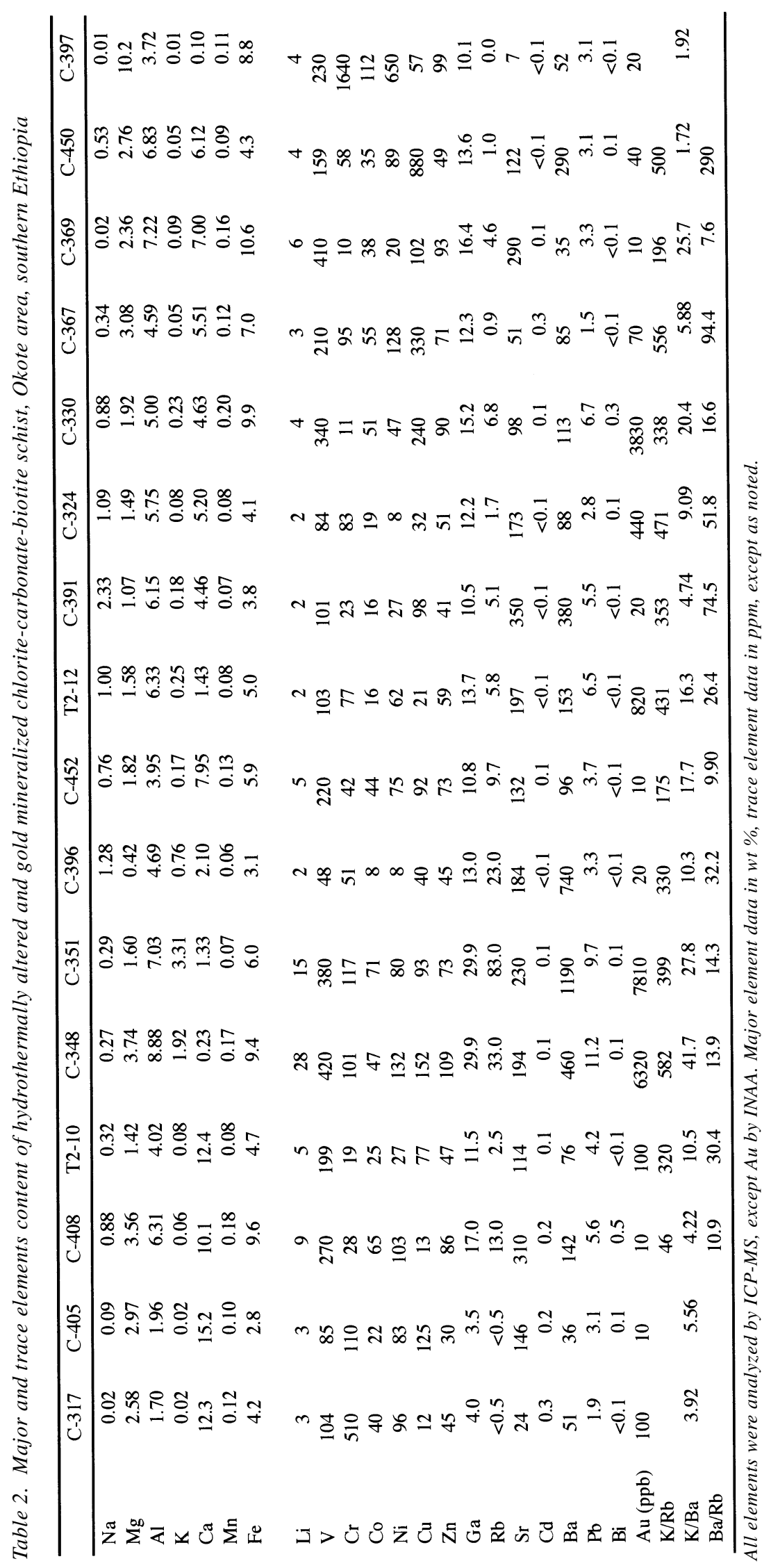




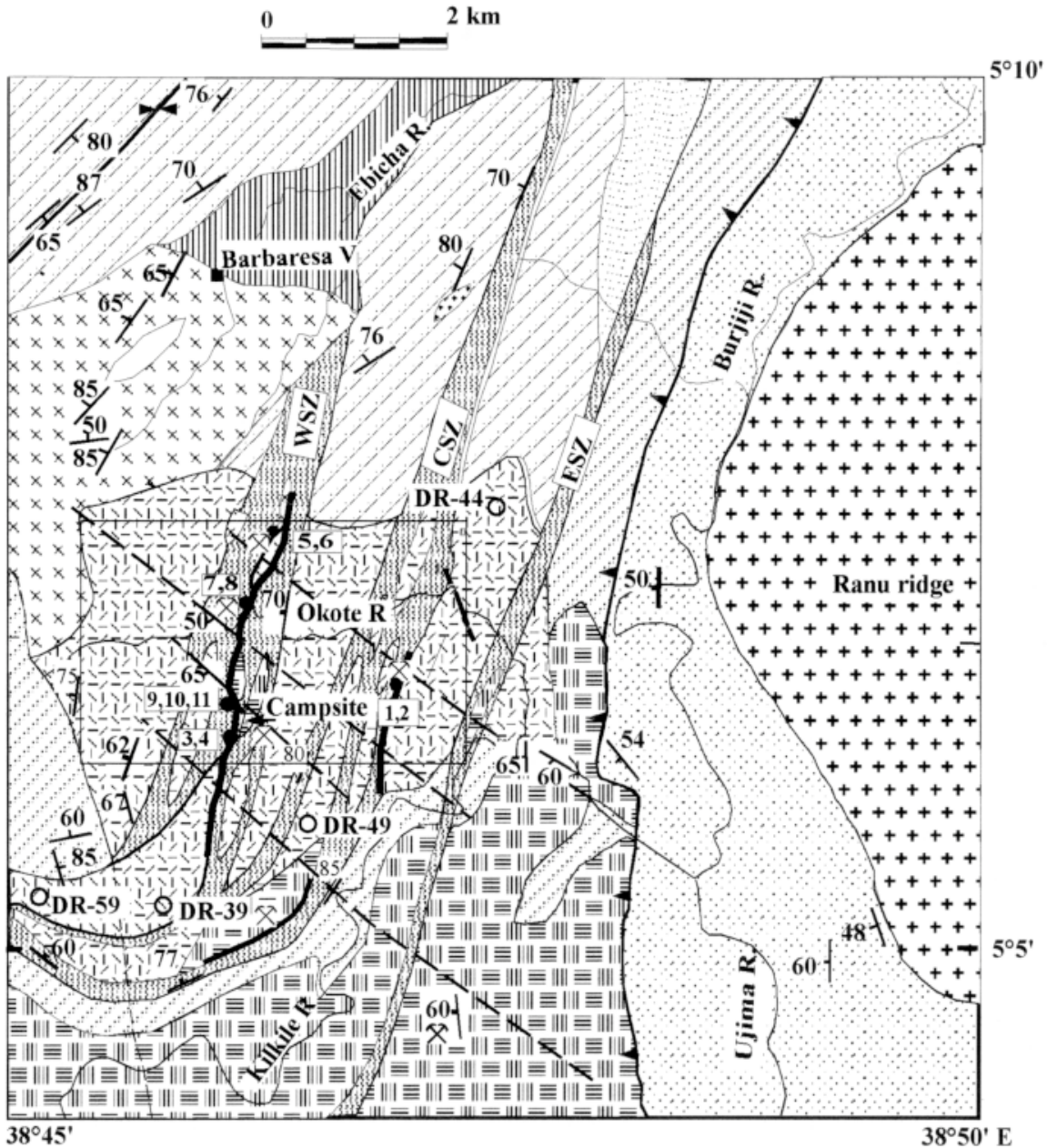

Legend

${ }^{\circ} 10^{\prime} \mathrm{N}$

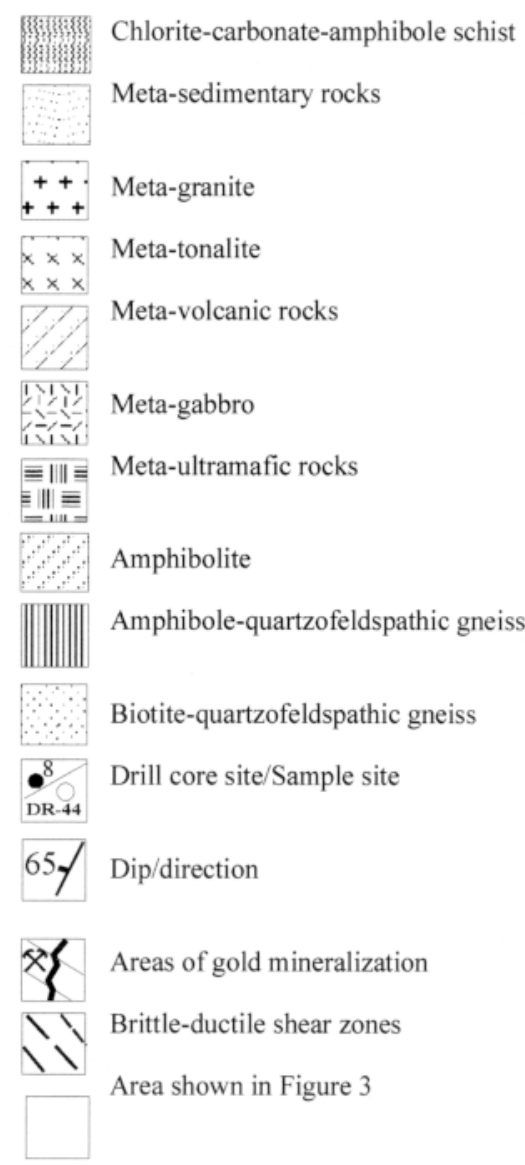

Fig. 2. Regional geological map of Okote area, southern Ethiopia, based on new fieldwork; ESZ = eastern shear zone; CSZ = central shear zone; $W S Z=$ western shear zone.

sity of Vienna. An accelerating voltage of $15 \mathrm{keV}$, a beam current of $20 \mathrm{nA}$, and a beam diameter of $2 \mu \mathrm{m}$ were used. Natural minerals were used as standards: olivine for $\mathrm{Mg}$ and $\mathrm{Si}$; albite for $\mathrm{Na}$; corundum for $\mathrm{Al}$; orthoclase for $\mathrm{K}$; wollastonite for $\mathrm{Ca}$; rutile for $\mathrm{Ti}$; $\mathrm{Mg}$-chromite for $\mathrm{Cr}$; spessartine for $\mathrm{Mn}$; almandine for Fe. Row data were processed using Pouchou and Pichoir (1991) ZAF correction program.

\section{Fluid inclusion study}

Detailed fluid inclusion petrography was conducted on polished plates prior to heating and freezing experiment. Fluid inclusions were located under low magnification, their distribution, origin, and textural relationship determined and their phase relationships were studied under high objectives of microscope. The primary and secondary inclusions have been identified following the criteria outlined by Roedder (1984).
An Olympus BH-2 microscope with 40X to 500X magnification and Linkam THM-600 heating and freezing stage in the Institute of Mineralogy and Crystallography, University of Vienna, were used for the microthermometric study. The accuracy of the measurement was ensured by calibrating the Linkam THM-600 with the triple point of $\mathrm{CO}_{2}\left(-56.5^{\circ} \mathrm{C}\right)$, freezing of pure water $\left(0^{\circ} \mathrm{C}\right)$, and melting points of different components. Precisions of the temperature measurement are within $\pm 1^{\circ} \mathrm{C}$ for heating and for freezing. The salinity was calculated from the temperature of melting of ice $\left(T \mathrm{~m}_{\text {ice }}\right)$ using equation of Bodnar (1993). If $\mathrm{CO}_{2}$ clathration were recorded, salinity were determined using the clathrate melting curve of Collins (1979).

Stable isotope analysis

For the stable isotope study of carbonate and pyrite, we collected representative fresh outcrop and bore hole 
Table 3a. Selected electron microprobe analyses of chlorite* in the mineralized part of the Okote area

\begin{tabular}{|c|c|c|c|c|c|c|c|c|c|c|}
\hline & \multicolumn{2}{|c|}{ BH11-107 } & \multicolumn{2}{|c|}{ BH10-84 } & \multicolumn{2}{|c|}{ BH10-68 } & \multicolumn{2}{|c|}{ DR-2 } & \multicolumn{2}{|c|}{ DR-18 } \\
\hline & Chl & $\mathrm{Ch} 2$ & $\mathrm{Ch} 3$ & Ch4 & Ch5 & Ch6 & $\mathrm{Ch} 7$ & Ch8 & Ch9 & Ch10 \\
\hline $\mathrm{SiO}_{2}$ & 24.82 & 30.70 & 26.83 & 27.69 & 26.10 & 27.04 & 24.41 & 25.34 & 26.72 & 25.98 \\
\hline $\mathrm{TiO}_{2}$ & 0.07 & 0.03 & 0.08 & 0.07 & 0.09 & 0.06 & 0.06 & 0.05 & 0.07 & 0.16 \\
\hline $\mathrm{Al}_{2} \mathrm{O}_{3}$ & 23.60 & 25.48 & 21.77 & 20.83 & 22.00 & 21.23 & 24.00 & 23.10 & 21.95 & 22.26 \\
\hline $\mathrm{FeO}$ & 20.81 & 17.43 & 16.53 & 16.16 & 18.48 & 17.49 & 21.82 & 19.36 & 17.00 & 16.53 \\
\hline $\mathrm{MnO}$ & 0.22 & 0.16 & 0.17 & 0.17 & 0.19 & 0.16 & 0.13 & 0.13 & 0.07 & 0.09 \\
\hline $\mathrm{MgO}$ & 17.07 & 12.89 & 21.36 & 22.19 & 19.60 & 20.41 & 16.80 & 18.45 & 21.08 & 20.74 \\
\hline Total & 86.57 & 86.69 & 86.73 & 87.12 & 86.46 & 86.39 & 87.22 & 86.42 & 86.89 & 85.75 \\
\hline $\mathrm{Si}$ & 5.16 & 6.12 & 5.44 & 5.57 & 5.37 & 5.52 & 5.06 & 5.24 & 5.41 & 5.32 \\
\hline $\mathrm{Al}^{\mathrm{IV}}$ & 2.84 & 2.89 & 2.56 & 2.43 & 2.63 & 2.48 & 2.93 & 2.77 & 2.59 & 2.68 \\
\hline $\mathrm{Al}^{\mathrm{VI}}$ & 2.94 & 4.10 & 2.64 & 2.51 & 2.70 & 2.63 & 2.94 & 2.86 & 2.64 & 2.70 \\
\hline $\mathrm{Ti}$ & 0.01 & 0.01 & 0.01 & 0.01 & 0.01 & 0.01 & 0.02 & 0.01 & 0.01 & 0.02 \\
\hline $\mathrm{Fe}$ & 3.62 & 2.90 & 2.80 & 2.72 & 3.18 & 2.99 & 3.77 & 3.35 & 2.88 & 2.83 \\
\hline $\mathrm{Mn}$ & 0.04 & 0.03 & 0.03 & 0.03 & 0.03 & 0.03 & 0.02 & 0.02 & 0.01 & 0.02 \\
\hline $\mathrm{Mg}$ & 5.29 & 3.83 & 6.45 & 6.66 & 6.01 & 6.21 & 5.20 & 5.68 & 6.36 & 6.34 \\
\hline $\mathrm{Z}$ & 8 & 8 & 8 & 8 & 8 & 8 & 8 & 8 & 8 & 8 \\
\hline $\mathrm{Y}$ & 11.90 & 10.86 & 11.93 & 11.94 & 11.94 & 11.88 & 11.95 & 11.92 & 11.91 & 11.90 \\
\hline Xmg & 0.59 & 0.57 & 0.70 & 0.71 & 0.65 & 0.68 & 0.58 & & 0.69 & 0.69 \\
\hline
\end{tabular}

*Structural formula of the chlorite based on 28 number of oxygens.

Table 3b. Selected electron microprobe analyses of biotite** in the mineralized part of the Okote area

\begin{tabular}{|c|c|c|c|c|c|c|c|c|c|c|}
\hline & \multicolumn{2}{|c|}{ BH11-107 } & \multicolumn{2}{|c|}{ BH10-85 } & \multicolumn{2}{|c|}{ BH10-68 } & \multicolumn{2}{|c|}{ BH9-194 } & \multicolumn{2}{|c|}{ BH9-192 } \\
\hline & B1 & B2 & B3 & B4 & $\mathrm{B} 5$ & B6 & B7 & B8 & B9 & $\mathrm{B} 10$ \\
\hline $\mathrm{SiO}_{2}$ & 35.91 & 36.69 & 36.54 & 36.03 & 36.21 & 36.05 & 37.41 & 37.75 & 35.74 & 36.08 \\
\hline $\mathrm{TiO}_{2}$ & 2.45 & 1.69 & 1.79 & 1.63 & 4.37 & 1.81 & 1.17 & 1.40 & 2.41 & 2.11 \\
\hline $\mathrm{Al}_{2} \mathrm{O}_{3}$ & 17.09 & 17.19 & 16.58 & 16.14 & 17.53 & 18.22 & 15.86 & 15.88 & 16.33 & 16.48 \\
\hline $\mathrm{FeO}$ & 19.01 & 17.46 & 16.49 & 17.51 & 16.03 & 15.12 & 15.37 & 15.29 & 18.82 & 17.18 \\
\hline $\mathrm{MnO}$ & 0.16 & 0.10 & 0.04 & 0.03 & 0.10 & 0.07 & 0.21 & 0.17 & 0.20 & 0.18 \\
\hline $\mathrm{MgO}$ & 9.48 & 12.25 & 13.26 & 13.61 & 9.87 & 12.71 & 13.99 & 14.12 & 10.82 & 12.13 \\
\hline $\mathrm{CaO}$ & 0.16 & b.d. & b.d. & b.d. & b.d. & b.d. & b.d. & 0.05 & b.d. & 0.03 \\
\hline $\mathrm{Na}_{2} \mathrm{O}$ & 0.03 & 0.27 & 0.06 & 0.08 & 0.03 & 0.09 & 0.09 & 0.10 & 0.07 & 0.05 \\
\hline $\mathrm{K}_{2} \mathrm{O}$ & 9.70 & 9.13 & 9.15 & 8.93 & 9.64 & 9.14 & 9.71 & 9.30 & 8.69 & 9.42 \\
\hline Total & 94.01 & 94.78 & 93.91 & 93.95 & 93.77 & 93.21 & 93.82 & 94.05 & 93.09 & 93.66 \\
\hline $\mathrm{Si}$ & 5.55 & 5.55 & 5.56 & 5.51 & 5.52 & 5.48 & 5.68 & 5.70 & 5.55 & 5.54 \\
\hline $\mathrm{Al}^{\mathrm{IV}}$ & 2.45 & 2.45 & 2.44 & 2.49 & 2.48 & 2.52 & 2.32 & 2.30 & 2.45 & 2.46 \\
\hline $\mathrm{Al}^{\mathrm{VI}}$ & 0.67 & 0.62 & 0.53 & 0.42 & 0.66 & 0.75 & 0.52 & 0.52 & 0.45 & 0.53 \\
\hline $\mathrm{Ti}$ & 0.29 & 0.19 & 0.21 & 0.19 & 0.50 & 0.21 & 0.13 & 0.16 & 0.28 & 0.24 \\
\hline $\mathrm{Fe}$ & 2.46 & 2.21 & 2.10 & 2.24 & 2.04 & 1.92 & 1.95 & 1.93 & 2.44 & 2.21 \\
\hline Mn & 0.02 & 0.01 & & 0.00 & 0.01 & 0.01 & 0.03 & 0.02 & 0.03 & 0.02 \\
\hline $\mathrm{Mg}$ & 2.19 & 2.76 & 3.01 & 3.10 & 2.24 & 2.88 & 3.17 & 3.18 & 2.51 & 2.78 \\
\hline $\mathrm{Ca}$ & 0.03 & & & & & & & 0.01 & & 0.01 \\
\hline $\mathrm{Na}$ & 0.01 & 0.08 & 0.02 & 0.02 & 0.01 & 0.03 & 0.03 & 0.03 & 0.02 & 0.01 \\
\hline K & 1.91 & 1.76 & 1.78 & 1.74 & 1.87 & 1.77 & 1.88 & 1.79 & 1.72 & 1.85 \\
\hline $\mathrm{Fe} /(\mathrm{Fe}+\mathrm{Mg})$ & 0.53 & 0.44 & 0.41 & 0.42 & 0.48 & 0.40 & 0.38 & 0.38 & 0.49 & 0.44 \\
\hline $\mathrm{Al} /(\mathrm{Al}+\mathrm{Si})$ & 0.36 & 0.36 & 0.35 & 0.35 & 0.36 & 0.37 & 0.33 & 0.33 & 0.35 & 0.35 \\
\hline
\end{tabular}

**Structural formula based on 22 number of oxygens.

b.d. $=$ below detection limit . 
Table 3c. Selected electron microprobe analyses of amphiboles in the mineralized part of the Okote area

\begin{tabular}{|c|c|c|c|c|c|c|c|c|c|}
\hline & \multicolumn{3}{|c|}{ BH10-84 } & \multicolumn{3}{|c|}{ BH9-192 } & \multicolumn{3}{|c|}{ BH11-109 } \\
\hline & AM1 & AM2 & AM3 & AM4 & AM5 & AM6 & AM7 & AM8 & AM9 \\
\hline $\mathrm{SiO}_{2}$ & 45.02 & 47.01 & 44.13 & 43.32 & 54.52 & 44.72 & 42.67 & 53.53 & 45.57 \\
\hline $\mathrm{TiO}_{2}$ & 0.31 & 0.31 & 0.33 & 0.41 & 0.01 & 0.35 & 0.35 & 0.07 & 0.34 \\
\hline $\mathrm{Al}_{2} \mathrm{O}_{3}$ & 11.47 & 10.10 & 12.18 & 11.77 & 2.03 & 10.77 & 12.69 & 2.58 & 9.52 \\
\hline $\mathrm{Fe}_{2} \mathrm{O}_{3}$ & 1.88 & 1.13 & 1.93 & 1.12 & 1.08 & 1.87 & 1.54 & 0.59 & 1.68 \\
\hline $\mathrm{FeO}$ & 13.04 & 12.68 & 13.53 & 15.68 & 10.13 & 14.77 & 15.92 & 10.97 & 14.55 \\
\hline $\mathrm{MnO}$ & 0.18 & 0.22 & 0.18 & 0.33 & 0.31 & 0.38 & 0.35 & 0.37 & 0.33 \\
\hline $\mathrm{MgO}$ & 11.73 & 12.79 & 11.03 & 9.64 & 17.29 & 10.78 & 9.29 & 16.54 & 11.20 \\
\hline $\mathrm{CaO}$ & 11.95 & 12.02 & 11.95 & 11.52 & 12.57 & 11.54 & 11.50 & 12.27 & 11.69 \\
\hline $\mathrm{Na}_{2} \mathrm{O}$ & 1.23 & 1.06 & 1.28 & 1.29 & 0.20 & 1.18 & 1.44 & 0.28 & 1.13 \\
\hline $\mathrm{K}_{2} \mathrm{O}$ & 0.18 & 0.13 & 0.24 & 0.38 & 0.030 & 0.27 & 0.43 & 0.08 & 0.15 \\
\hline Total & 97.00 & 97.44 & 96.78 & 95.46 & 98.18 & 96.62 & 96.18 & 97.28 & 96.16 \\
\hline $\mathrm{Si}$ & 6.69 & 6.89 & 6.60 & 6.62 & 7.76 & 6.74 & 6.51 & 7.71 & 6.87 \\
\hline $\mathrm{Al}^{\mathrm{IV}}$ & 1.31 & 1.11 & 1.40 & 1.38 & 0.24 & 1.27 & 1.49 & 0.29 & 1.13 \\
\hline $\mathrm{Al}^{\mathrm{VI}}$ & 0.70 & 0.63 & 0.75 & 0.74 & 0.10 & 0.65 & 0.79 & 0.14 & 0.57 \\
\hline $\mathrm{Ti}$ & 0.04 & 0.03 & 0.03 & 0.05 & 0.00 & 0.04 & 0.04 & 0.01 & 0.04 \\
\hline $\mathrm{Fe}^{3+}$ & 0.21 & 0.12 & 0.22 & 0.13 & 0.12 & 0.21 & 0.18 & 0.06 & 0.19 \\
\hline $\mathrm{Mg}$ & 2.43 & 2.64 & 2.30 & 2.04 & 3.55 & 2.21 & 1.93 & 3.42 & 2.35 \\
\hline $\mathrm{Fe}^{2+}$ & 1.60 & 1.54 & 1.67 & 2.00 & 1.20 & 1.84 & 2.02 & 1.32 & 1.82 \\
\hline $\mathrm{Mn}$ & 0.02 & 0.03 & 0.02 & 0.04 & 0.04 & 0.05 & 0.05 & 0.05 & 0.04 \\
\hline $\mathrm{Mg}$ & 0.17 & 0.16 & 0.16 & 0.16 & 0.12 & 0.21 & 0.18 & 0.13 & 0.17 \\
\hline $\mathrm{Ca}$ & 1.83 & 1.85 & 1.84 & 1.85 & 1.88 & 1.79 & 1.82 & 1.87 & 1.83 \\
\hline $\mathrm{Na}$ & 0.36 & 0.30 & 0.37 & 0.38 & 0.06 & 0.35 & 0.43 & 0.08 & 0.33 \\
\hline K & 0.03 & 0.03 & 0.05 & 0.07 & 0.01 & 0.05 & 0.08 & 0.02 & 0.03 \\
\hline $\mathrm{T}$ & 8 & 8 & 8 & 8 & 8 & 8 & 8 & 8 & 8 \\
\hline C & 5 & 5 & 5 & 5 & 5 & 5 & 5 & 5 & 5 \\
\hline B & 2 & 2 & 2 & 2 & 2 & 2 & 2 & 2 & 2 \\
\hline A & 0.46 & 0.37 & 0.49 & 0.50 & 0.10 & 0.47 & 0.57 & 0.11 & 0.42 \\
\hline Xmg & 0.62 & 0.64 & 0.60 & 0.52 & 0.75 & 0.57 & 0.51 & 0.73 & 0.58 \\
\hline
\end{tabular}

samples from carbonate veins and mineralized wall rocks. The samples were coarsely crushed and pure carbonate and pyrite crystals were separated by hand under a binocular microscope. The pure crystals were pulverized in an agate mill to -200 mesh size.

Six carbonate samples of about $200 \mu \mathrm{g}$ were loaded into reaction vials. The sample cups, of $3 \mathrm{~mm}$ thick silicone septum and a thin Kel-F septum, were fitted and kept overnight in a clean oven at $50^{\circ} \mathrm{C}$. The carbonates were treated with phosphoric acid at a temperature of $90^{\circ} \mathrm{C}$ to liberate $\mathrm{CO}_{2}$. For sulfur isotope analysis, 10 pyrite samples of $50 \mu \mathrm{g}$ were analyzed by the combustion method (Morrison et al., 1996).

The obtained gases $\left(\mathrm{CO}_{2}\right.$ and $\left.\mathrm{SO}_{2}\right)$ were analyzed for their isotopic composition using an OPTIMA dual inlet stable isotope ratio mass spectrometer at the University of Vienna, Austria. The results are reported in $\delta$ units with reference to international standards (CDT for sulfur, SMOW for oxygen and PDB for carbon, Hoefs, 1997). The reproducibility of the analyses was $\pm 0.23 \%$ o for sulfur and $\pm 0.01 \%$ o for oxygen and carbon isotopes.

\section{GeOLOGY OF THE STUdy AREA}

The study area comprises biotite-quartzofeldspathic gneiss, amphibole-quartzofeldspathic gneiss, amphibolite, meta-ultramafic rocks, meta-gabbro, meta-volcanic rocks, meta-tonalite, meta-granite, meta-sedimentary rocks, and chlorite-carbonate-amphibole schist (Fig. 2).

Biotite-quartzofeldspathic gneiss and amphibolequartzofeldspathic gneiss represent the lowest stratigraphic units and have tectonic contact with the overlying mafic-ultramafic rocks (meta-ultramafic rocks, amphibolite, meta-gabbro, and meta-volcanic rocks). The thrust contacts dip at $30^{\circ}$ to $40^{\circ}$ towards $\mathrm{W}$ and NW and are characterized by intense deformation. The maficultramafic rocks constitute the hangingwall of the thrust surface and are schistose with intensity of deformation and grade of metamorphism decrease away from the thrust surface. The footwall consists of biotitequartzofeldspathic gneiss and displays recumbent folds those are verging toward E to SE, symmetrical to asymmetrical porphyroblasts of feldspars, and striation linea- 


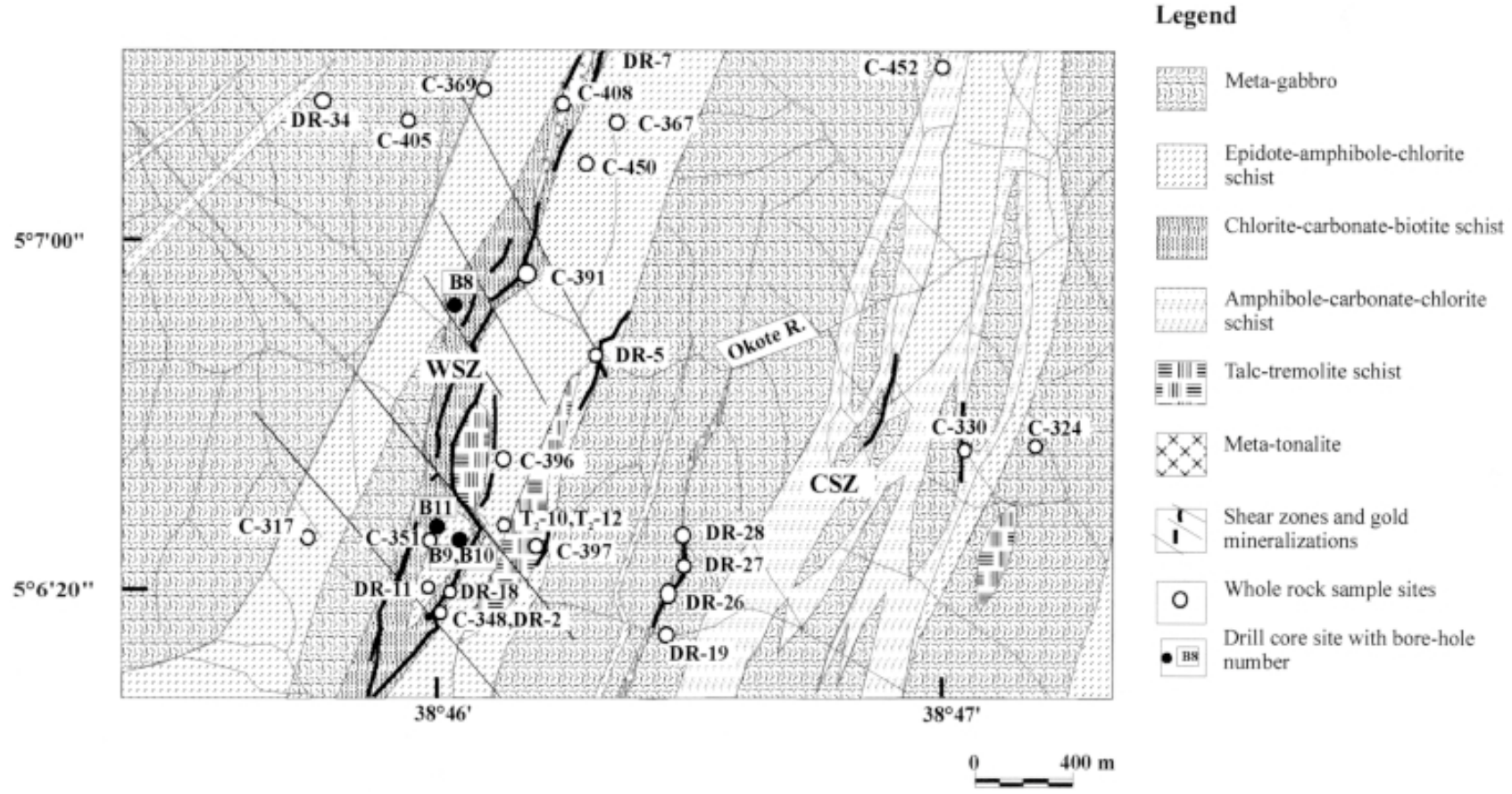

Fig. 3. Detailed geological map of the sheared, altered, and mineralized part of the Okote area, southern Ethiopia, based on new fieldwork.

tion, and pronounced tectonic foliation. The intensity of mineral lineation and tectonic foliation also decreases away from the thrust surface.

\section{Petrography of the host rocks}

The meta-gabbro cut by three main shear zones that host gold mineralization (Fig. 2).

Meta-gabbro Meta-gabbro has gradational contacts with the meta-volcanic and meta-ultramafic rocks, but sharp contacts with meta-granodiorite (Fig. 2). The meta-gabbro is dark green to gray in color, medium- to coarse-grained, granular in texture, and comprises clinopyroxene, plagioclase, orthopyroxene, and hornblende. Tremoliteactinolite, clinozoisite, chlorite, epidote, and prehnite are minor metamorphic minerals. Orthopyroxene mostly changed to tremolite-actinolite, whereas clinopyroxene is commonly rimmed by hornblende. In many places, hornblende and clinopyroxene were partially replaced by tremolite-actinolite, chlorite, accessory epidote, and clinozoisite. Plagioclase $\left(\mathrm{An}_{72-92}\right)$ is the dominant mineral in meta-gabbro and is commonly affected by saussuritization. Primary minerals and texture are decreasing as the shear zones are approached.

Chlorite-carbonate-amphibole schist The maficultramafic rocks of the Okote area cut by three main N-S trending ductile shear zones (eastern-, central-, and western shear zones; Fig. 2). The chlorite-carbonate-amphibole schist is highly sheared, foliated, and hydrothermally al- tered chlorite-carbonate-amphibole schist. Based on the characteristic minerals the schist can be grouped into three subordinate lithologic units. They are chlorite-carbonatebiotite schist, epidote-amphibole-chlorite schist, and amphibole-carbonate-chlorite schist. The intensity of shearing and hydrothermal alteration is highest in the chlorite-carbonate-biotite schist and is at a minimum in the epidote-amphibole-chlorite schist. The gold mineralization is associated mainly with the western shear zone. The petrographic descriptions of the rock units given below are for the central and western shear zones (Figs. 2 and 3).

Chlorite-carbonate-biotite schist The schist is the host rock of gold mineralization in the Okote area and is light green in color, fine grained, intensely foliated, and has abundant foliation concordant, pinching and swelling, auriferous quartz-carbonate-tourmaline veins. The mineral assemblages are mainly chlorite, carbonate (calcite and ankerite), quartz, albite, and biotite, minor epidoteclinozoisite, pyrite, muscovite, actinolite, and K-feldspar, and accessory magnetite, chalcopyrite, apatite, ilmenite, $\mathrm{TiO}_{2}$-minerals (rutile and anatase), pyrrhotite, covellite, and chalcocite. Chlorite is dominant in the schist and its contents reaches up to $45 \mathrm{vol} \%$ of the total mineral abundance of the schist. The chlorite is composed mainly of sheridanite and clinochlorite and minor rapidolitebrunsvigite. Carbonates are the second dominant mineral of the schist (constitutes up to 40 vol.\%), and comprise 

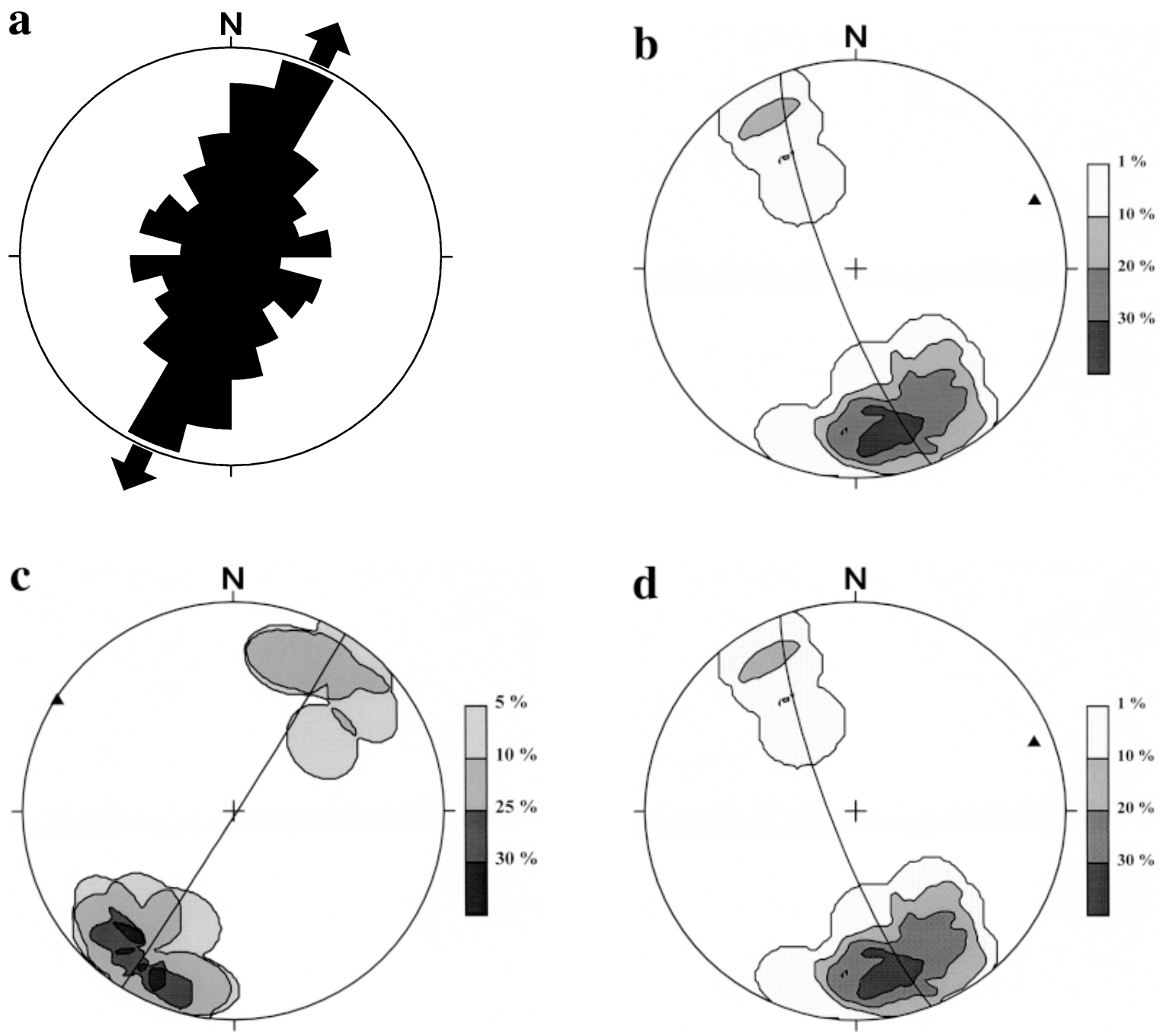

Fig. 4. Orientation of the shear zones: a) rose diagram showing orientation of the predominant N-S to NE striking shear foliation and stereonet diagrams (lower hemisphere equal area projection) of poles to b) $N$-S to NE striking shear foliation $(N=91)$, c) $N W$ striking brittle ductile shear foliation $(N=16)$ and $d) E$-W striking extension fractures $(N=18)$.

calcite and ankerite. Ankerite is partially replaced by calcite. Carbonates occur in disseminated form and in quartztourmaline-carbonate veins. Pyrite is the dominant sulfide mineral.

Epidote-amphibole-chlorite schist The schist occurs both in the hanging- and in the footwall of the chloritecarbonate-biotite schist and they have a gradational contact. Relict inclusions of the schist in chlorite-carbonatebiotite schist have been observed. The schist is fine- to medium-grained, well foliated, and consists mainly of clinozoisite-epidote, actinolite, hornblende, plagioclase, and chlorite and accessory albite, pyrite, magnetite, and apatite. Plagioclase $\left(\mathrm{An}_{23-31}\right)$ is partly altered to epidote and albite. Amphibole shows zoning with ferroactinolite cores and ferro-hornblende rims, indicating prograde metamorphism. Chlorite and calcite suggesting hydrothermal alteration commonly replace the actinolite and hornblende.

Amphibole-carbonate-chlorite schist The schist is mainly exposed in the eastern part of the mineralized Okote area (Figs. 2 and 3). The schist is green in color, medium-grained, well foliated, and composed of tremolite-actinolite, hornblende, carbonate, chlorite, albite, and accessory epidote zoisite/clinozoisite, muscovite, pyrite, biotite, iron oxides, and relic plagioclase. Tremolite-actinolite and carbonate are the dominant minerals. The schist contains quartz-carbonate-tourmaline veins that are enveloped by the intensively sheared wall rocks those are comparable with the chlorite-carbonatebiotite schist. 


\section{ShEARING, Alteration, AND Gold Mineralization}

\section{Shearing and alteration}

Two major and a minor shear zones are encountered in the Okote mineralized zones (Fig. 4a). The two major structures are the dominant $\mathrm{N}-\mathrm{S}$ striking ductile shear zone (Fig. 4b) and subordinate younger NW-SE trending brittle ductile structures (Fig. 4c). The third minor structures are those strike E-W (Fig. 4d).

The N-S trending shear zones have an anastomosing pattern with intervening lenses of less-deformed mafic to ultramafic rocks and dip moderately to steeply $\left(60^{\circ}\right.$ to $\left.85^{\circ}\right)$ towards $\mathrm{W}$ to $\mathrm{NW}\left(270^{\circ}\right.$ to $\left.330^{\circ}\right)$.

Structural and alteration zonings have been observed within the N-S trending shear zones. The shearing and alteration features given below are for the central- and western shear zones. Field relationships, as well as microstructures, indicates a gradual transition from apparently undeformed protolith through a transitional zone to the mylonite zone, suggesting increasing strain during progressive deformation.

Protolith Apparently undeformed protolith (e.g., metagabbro) boudins occur in the shear zones in various forms, sizes, and internal structures (Fig. 5a). The boudins are commonly elongated parallel to the shear zone boundary and show parallel brittle fractures or joints perpendicular to their long axes. These fractures strike E-W and dip steeply towards the North, and terminate against ductile shear bands. These fractures are most commonly filled by quartz- and quartz-carbonate veinlets commonly less than $10 \mathrm{~cm}$ wide. Most of the fractures in small boudins, particularly that in wide shear zones, are a few centimeters in width and have symmetrical alteration halos indicating extensive fluid circulation during and/or after fracture development.

Transitional zones A transitional zone (protomylonite) a few hundred meters long and centimeter to tens of meters wide, marks the area between the protolith (e.g., metagabbro) and the mylonite zone. This zone consists of epidote-amphibole-chlorite schist (Fig. 5b). Tremolite gradually changes to chlorite with increasing intensity of shearing and hydrothermal alteration. Plagioclase and quartz are more competent than other minerals and commonly forms symmetric to asymmetric porphyroclasts. Extension fractures were developed perpendicular to the elongation direction of the porphyroclasts. These extension fractures are the main vehicle leading to porphyroclast size reduction and are always associated with hydrothermal alteration. Quartz porphyroclasts have a variety of sizes and contain aggregates of quartz crystals that show undulose extinction and deformation bands. Recrystallization of quartz at the pressure shadows of quartz and plagioclase porphyroclasts is common.

Mylonite zones The mylonite zones represents the most highly sheared, hydrothermally altered, and mineralized
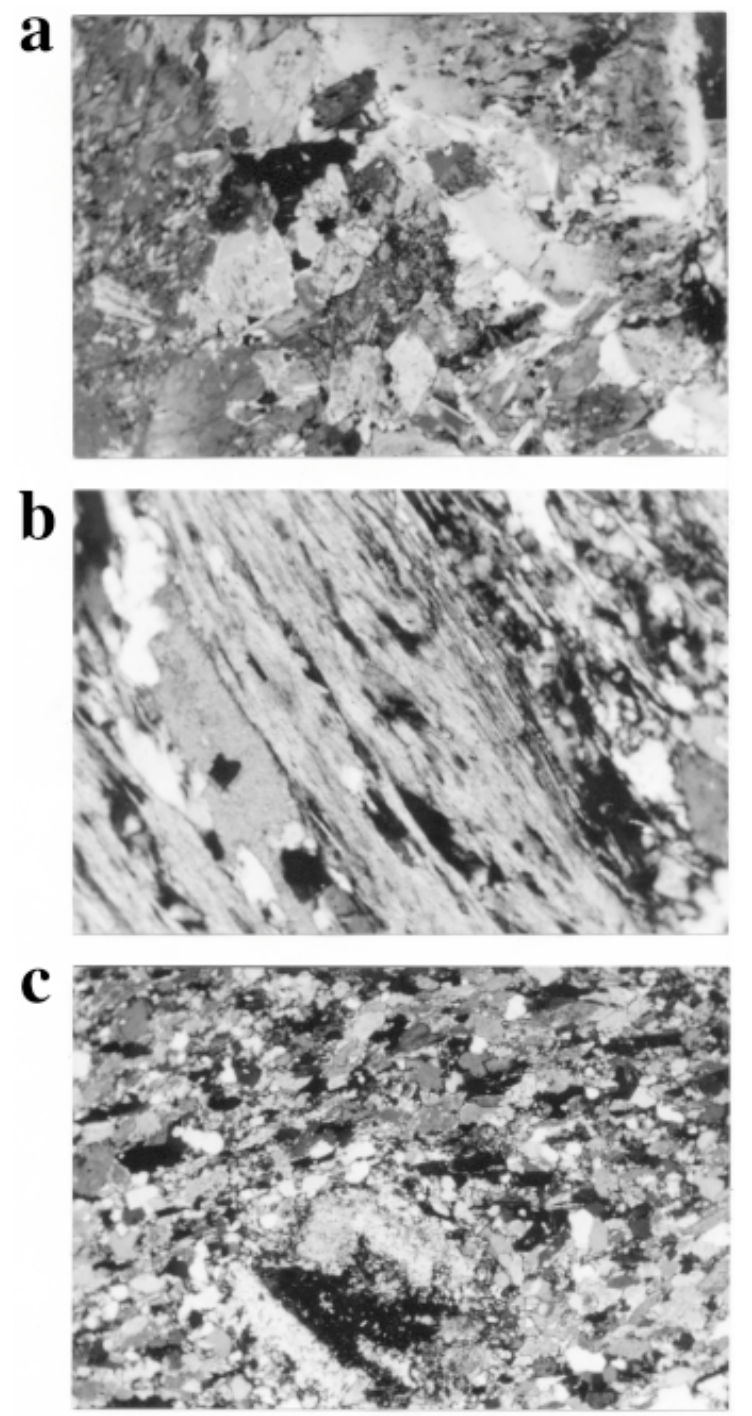

Fig. 5. Microphotographs showing different intensities of shearing and alteration of meta-gabbro; width of all images is 2.25 mm; all were taken under crossed polars. a) Meta-gabbro consisting of relicts of orthopyroxene, clinopyroxene, and plagioclase and alteration products, tremolite and epidote group minerals. $b$ ) This rock has a blastomylonitic texture and is composed of plagioclase porphyroclasts and amphiboles, quartz, epidote, and feldspar matrix. The dominant fabric of this rock is schistosity defined by aligned plates of amphibole. The plagioclase porphyroclast contains inclusions of epidote group minerals due to alteration. c) Highly deformed (sheared) rock composed of chlorite, carbonate, and biotite. The rock shows well-developed foliation, as shown by remarkable preferential parallel orientation of chlorite and biotite and dimensional elongation of carbonate, quartz, and pyrite.

part of the shear zones. The mylonite zones contain an anastomosing network of shear foliations. Plagioclase and quartz porphyroclasts completely removed during intense shearing and hydrothermal alteration (Fig. 5c). Pervasive 

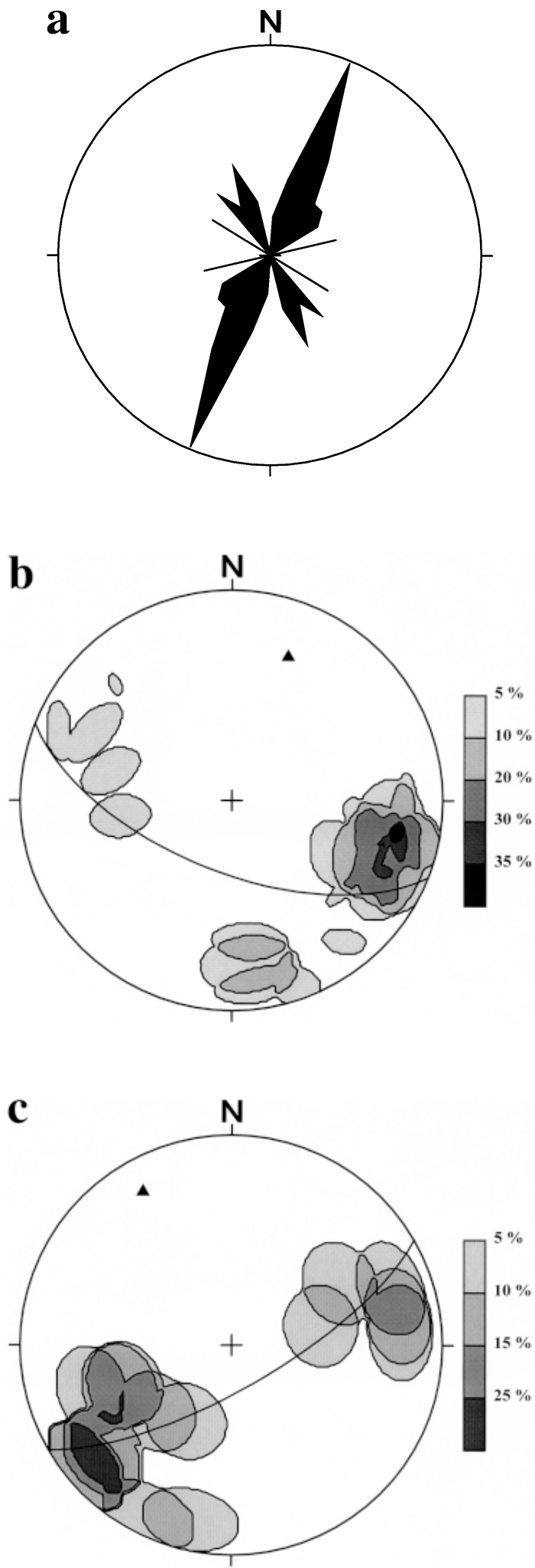

Fig. 6. Quartz veins a) rose diagram showing NE striking predominant $q v_{2}$ and subordinate $N W$ striking $q v_{3}$ vein and stereonet diagrams (lower hemisphere equal-area projection) of b) $\mathrm{N}$-S shear foliation concordant q $v_{2}$ veins and c) $\mathrm{NW}$ striking brittle-ductile shear foliation concordant $q v_{3}$ veins. mylonitic fabric is defined by grain-size reduction, dynamic recrystallization, preferred orientation chlorite, carbonates, biotite, fine quartz aggregates, and by occurrences of ribbon-type quartz veins. Domains rich in alternating mafic minerals (e.g., chlorite and biotite) and light colored minerals (quartz and carbonate) are ubiquitous. The older pyrites grains are drawn out and flattened in the plane of mylonite foliation and are commonly mantled by chlorite and biotite. High schistosity, high abundance of quartz veins and enrichment of pyrite, biotite, $\mathrm{K}$-feldspar and gold also characterize the mylonite zones. These quartz veins show boudinage and pinch and swell structure along their strike direction indicating progressive deformation.

\section{Quartz veins}

Three main stages of quartz vein formation have been detected based on their intersection relationship and their occurrence with respect to the foliation of the host rocks. These are E-W trending highly deformed quartz veins $\left(\mathrm{qv}_{1}\right)$, concordant $\mathrm{N}-\mathrm{S}$ to $\mathrm{N} 20^{\circ} \mathrm{E}$ striking quartzcarbonate-tourmaline veins $\left(\mathrm{qv}_{2}\right)$, and NW striking discordant veins $\left(\mathrm{qv}_{3}\right)$. The oldest generation $\mathrm{qv}_{1}$ veins are the least in abundance, the oldest, most highly deformed veins, and are not gold mineralized.

The $\mathrm{qv}_{2}$ veins are the most studied veins due to their native gold contents. The $\mathrm{qv}_{2}$ veins, strikes $\mathrm{N}-\mathrm{S}$ to $\mathrm{N} 20^{\circ} \mathrm{E}$ (Fig. 6a), dip subvertically towards the west (Fig. 6b) and show pinch and swell structure. The $\mathrm{qv}_{2}$ veins are quartzcarbonate veins, quartz-carbonate-tourmaline veins, and quartz veins and composed mainly of quartz, carbonates, and tourmaline, and accessory pyrite, chalcopyrite, and native gold. Wall rock alterations and their characteristic features are composed of chlorite, carbonate, biotite, pyrite, and gold. Native gold grains in these veins commonly occur within fractures and wall rock inclusions. The $\mathrm{qv}_{2}$ veins are intensely deformed in many places due to progressive N-S shear deformation. They show boudinage, folding, undulose extinction, deformation bands or lamella, and recovery or recrystallization textures. The youngest veins $\left(\mathrm{qv}_{3}\right)$ are very thin, dip at $70^{\circ}$ towards $\mathrm{SW}$, occur in brittle fractures, and are not gold mineralized (Fig. 6c).

\section{Gold mineralization}

Field-, microscopic-, and electron microprobe studies of samples from the Okote area gold mineralization revealed the occurrences of gold in association with pyrite. Mineralization is restricted to the anastomosing system of narrow high strain, N-S trending ductile shear zones. Within the shear zones, gold grains occur in the second generation veins $\left(\mathrm{qv}_{2}\right)$.

Ore mineralogy The ore minerals of the Okote area are dominantly pyrite, minor magnetite, chalcopyrite, 
a

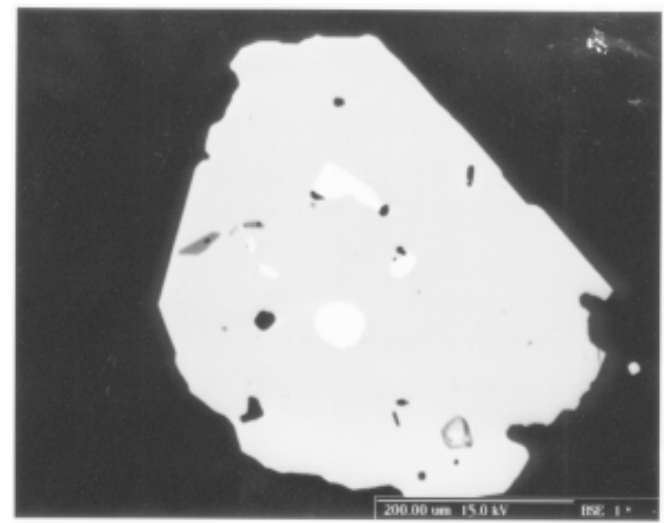

c

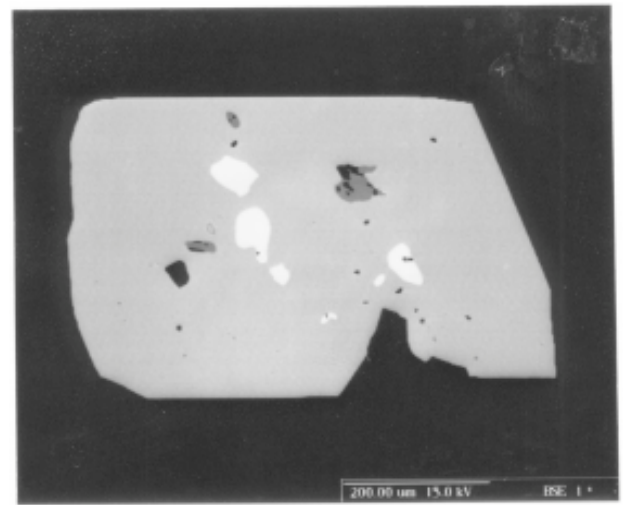

b

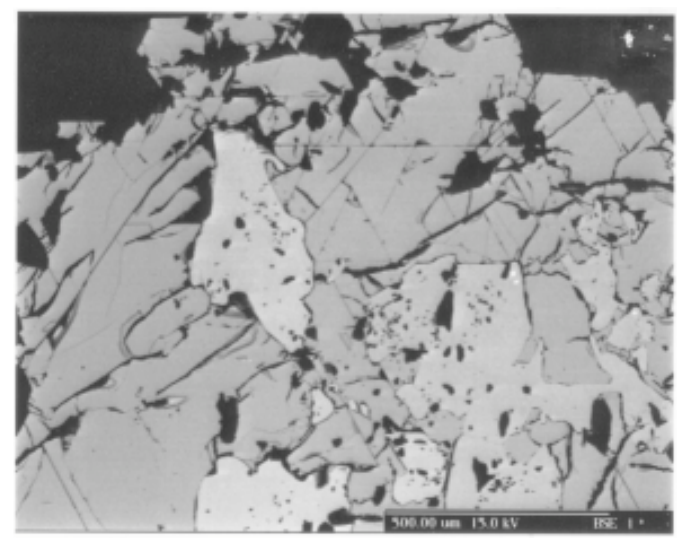

d

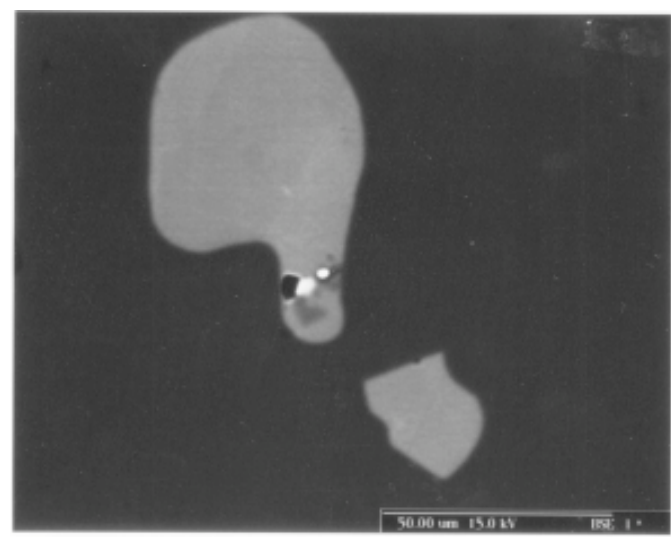

Fig. 7. Back-scattered electron images of a) pyrite I with concentric bright inclusion of pyrrhotite (granular grain and two small grains, lower left) and chalcopyrite I (long crystal and small granular grain, top right); b) Pyrite I (light gray) replacing magnetite (dark gray); c) euhedral pyrite II containing inclusions of chalcopyrite II one of the chalcopyrite contains very fine native gold (as enlarged in d).

pyrrhotite, and ilmenite, and accessory $\mathrm{TiO}_{2}$-minerals (rutile, anatase), chalcocite, covellite, native gold, galena, melonite $\left(\mathrm{NiTe}_{2}\right)$, and wolframite.

The ore minerals occur disseminated in the quartz veins and in the wall rock alterations. In places, cubic, very coarse-grained pyrite that occurs along shear fractures forming ore shoots those are up to two meters thick and have tens of meters strike length.

At least two generation of pyrite have been distinguished. Pyrite I is crystallized during early stage of shearing and hydrothermal alteration and occurs in the forms of porphyroblasts those dimensionally elongated parallel to the N-S foliations. Pyrite I occurs as fine- to coarsegrained, commonly anhedral porphyroblasts with extension fractures. These fractures are perpendicular to maximum elongation of porphyroblasts, and contain concentric inclusions of gangue and ore minerals. The common gangue minerals are chlorite, carbonate (ankerite and calcite), quartz, albite, white mica, epidote, and apatite. Chalcopyrite, pyrrhotite, gold, and wolframite are ore mineral inclusions in pyrite. The concentric distribution of pyrrhotite and chalcopyrite I in pyrite I suggest variation in fluid chemistry. Higher temperature pyrite, pyrrhotite and chalcopyrite growth and low sulfur concentration followed low temperature crystallization of pyrite. Finally, introduction of low temperature fluid after peak temperature caused regression of pyrrhotite to pyrite II. The growth pyrite II after pyrrhotite was accompanied by crystallization of chalcopyrite II, chalcocite, covellite, galena, and gold. Pyrite II commonly shows insignificant deformation and contains inclusion of chalcocite, covellite, galena, monazite and xenotime.

Two generation of chalcopyrite can be distinguished. Chalcopyrite I is paragenetically closely associated with pyrrhotite and commonly occurs as inclusions within pyrite I together with pyrrhotite (Fig. 7a) and is paragenetically younger than pyrrhotite. Chalcopyrite II is spatially associated with pyrite II (Fig. 7b), covellite, chalcocite, and galena. Magnetite is a common constituent of the hydrothermal alteration zones. It is medium- to coarse- 

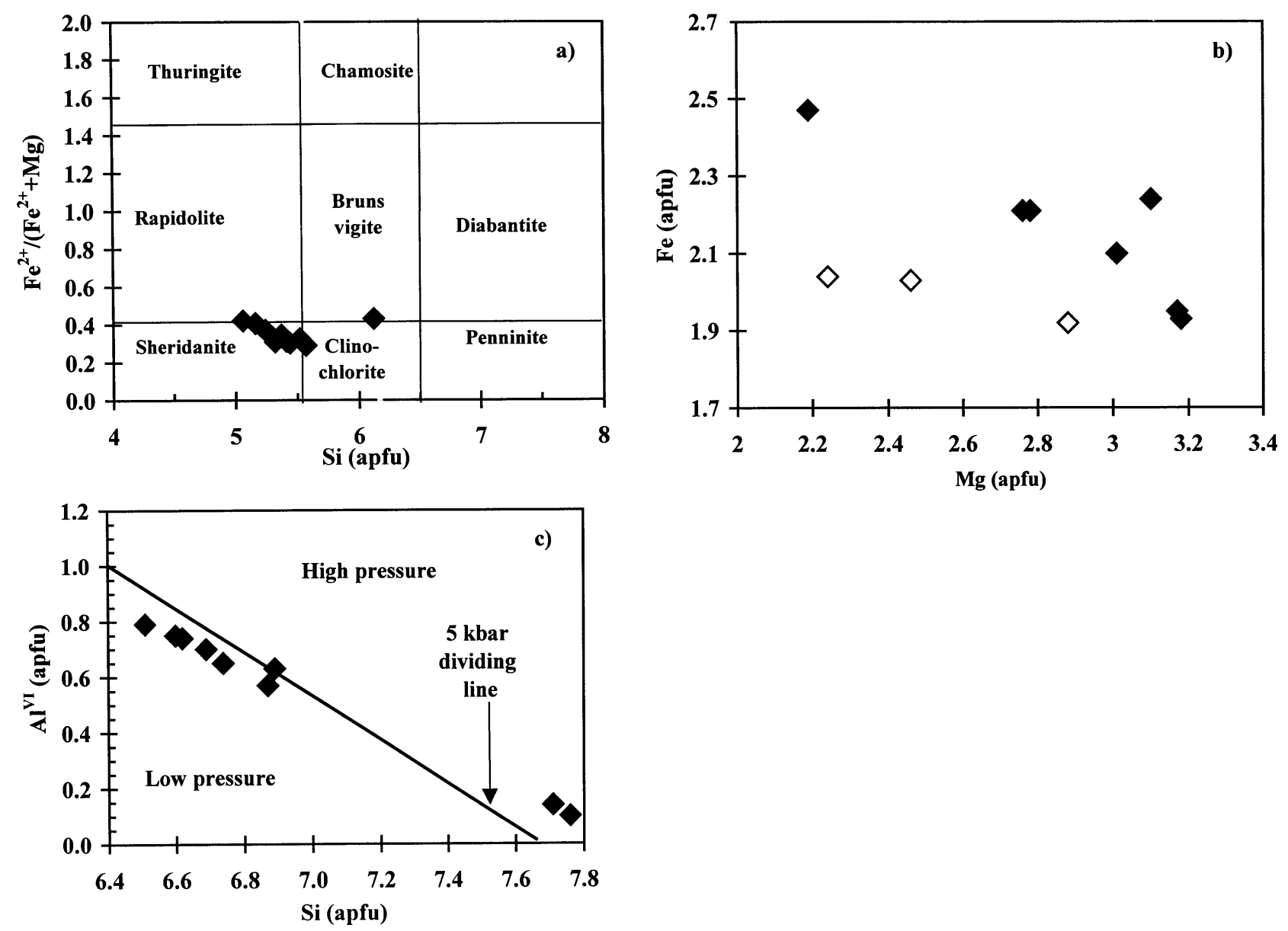

Fig. 8. Chemistry of selected minerals a) chemical classification of chlorite (fields after Foster, 1962), b) occurrences of two groups of biotite (biotite I, filled symbols; biotite II, open symbols), c) hornblende geobarometry (fields after Raase, 1974).

grained (up to $2 \mathrm{~cm}$ ), idiomorphic, black, and octahedral and commonly occurs in areas of low pyrite abundance. Microprobe study has shown that there is replacement of magnetite by pyrite (Fig. 7c) and chalcopyrite.

Gold is very fine-grained and occurs predominantly as native gold inclusion in chalcopyrite II $(\sim 5 \mu \mathrm{m}$; Fig. $7 \mathrm{~d})$ and pyrite. Very fine-grained native gold ( $25 \mu \mathrm{m}$ to 3 $\mathrm{mm}$ ) occurs in quartz vein associating with tourmaline and calcite.

Ilmenite is the common mineral in intensely altered areas. Ilmenite occurs as anhedral skeleton crystals and as acicular to tabular euhedral crystals. The former ilmenite contains fine-grained $\mathrm{TiO}_{2}$ (anatase or rutile) of variable size and shape. The latter ilmenite crystals occur as inclusion in pyrite and sphene. $\mathrm{TiO}_{2}$-minerals are very common in intensely altered zones. Very coarsegrained (up to $2 \mathrm{~mm}$ ) anhedral anatase occurs in the calcite-feldspar-quartz veinlet, indicating a secondary origin.

\section{GEOCHEMISTRY}

\section{Mineral chemistry}

Chlorite chemistry and geothermometry Chlorite is the most common mineral in gold mineralized part of the Okote area. Chlorite (on the basis of 28 oxygen) crystals show significant variation in the contents of $\mathrm{Si} 5.06$ to 6.26 apfu, Mg 1.64 to $6.91 \mathrm{apfu}$, and $\mathrm{Al}_{\mathrm{t}} 4.55$ to $5.98 \mathrm{apfu}$ (Table 3a). Plots of Mg vs. Fe contents clearly indicate the presence of two chlorite groups and show strong negative correlation between them. The $\mathrm{Al}^{\mathrm{VI}}$ and $\mathrm{Al}^{\mathrm{IV}}$ abundances of chlorite, in contrast, are negatively correlated. A plot of $\mathrm{Si}$ contents vs. $\mathrm{Fe} /(\mathrm{Fe}+\mathrm{Mg})$ ratios has been used to classify the chlorites into mainly sheridanite and clinochlorite and accessory brunsvigite and rapidolite (Foster, 1962; Fig. 8a). Cathelineau (1988) has discussed the use of chlorite as geothermometer and concluded that the Al-content in the tetrahedral site of chlorite is a function of the temperature of formation. The temperature has 
Table 4. Compositional changes for the transformation of parent rock (meta-gabbro) to hydrothermally altered products in the rocks from mineralized part of the Okote area

\begin{tabular}{|c|c|c|c|c|c|c|c|}
\hline & \multirow{2}{*}{$\begin{array}{c}\text { Fresh meta-gabbro } \\
\text { DR-44 }\end{array}$} & \multicolumn{2}{|c|}{ Chlorite-carbonate schist } & \multicolumn{2}{|c|}{ Epidote-amphibole-chlorite schist } & \multicolumn{2}{|c|}{ Amphibole-carbonate-chlorite schist } \\
\hline & & B $10-68$ & Gain/loss & DR-11 & Gain/loss & DR-5 & Gain/loss \\
\hline $\mathrm{SiO}_{2}$ & 50.11 & 47.16 & -4.52 & 51.93 & 3.81 & 47.19 & -2.80 \\
\hline $\mathrm{TiO}_{2}$ & 0.41 & 0.37 & -0.05 & 0.44 & 0.05 & 0.35 & -0.06 \\
\hline $\mathrm{Al}_{2} \mathrm{O}_{3}$ & 14.47 & 14.98 & 0.01 & 15.50 & 1.63 & 15.39 & 0.96 \\
\hline $\mathrm{Fe}_{2} \mathrm{O}_{3}$ & 9.47 & 10.12 & 0.31 & 11.17 & 2.13 & 11.10 & 1.66 \\
\hline $\mathrm{MnO}$ & 0.18 & 0.17 & -0.02 & 0.19 & 0.02 & 0.22 & 0.04 \\
\hline $\mathrm{MgO}$ & 10.08 & 6.43 & -3.86 & 5.56 & -4.31 & 6.74 & -3.32 \\
\hline $\mathrm{CaO}$ & 13.14 & 8.97 & -4.47 & 10.23 & -2.52 & 11.16 & -1.95 \\
\hline $\mathrm{Na}_{2} \mathrm{O}$ & 0.95 & 1.65 & 0.65 & 1.61 & 0.72 & 2.08 & 1.14 \\
\hline $\mathrm{K}_{2} \mathrm{O}$ & 0.10 & 0.68 & 0.56 & 0.07 & -0.03 & 0.11 & 0.01 \\
\hline $\mathrm{P}_{2} \mathrm{O}_{5}$ & 0.01 & 0.09 & 0.02 & 0.07 & 0.06 & 0.02 & 0.01 \\
\hline LOI & 1.66 & 9.02 & 7.06 & 1.85 & 0.26 & 5.29 & 3.64 \\
\hline Total & 100.49 & 99.58 & -4.22 & 98.63 & 1.93 & 99.65 & -0.58 \\
\hline V & 225 & 331 & 95.0 & 300 & 86.5 & 210 & -14.4 \\
\hline $\mathrm{Cr}$ & 64 & 71 & 5.03 & 29.7 & -33.1 & 97.7 & 33.9 \\
\hline Co & 49 & 30 & -20.1 & 35.9 & -11.7 & 42.7 & -6.19 \\
\hline $\mathrm{Ni}$ & 87 & 37 & -51.2 & 24 & -62.0 & 81 & -5.79 \\
\hline $\mathrm{Cu}$ & & 35 & 33.8 & 17 & 17.6 & 6 & 6.12 \\
\hline $\mathrm{Zn}$ & 67 & 69 & -0.29 & 82 & 18.1 & 93 & 26.2 \\
\hline $\mathrm{Rb}$ & 9 & 10 & 0.67 & 14 & 5.64 & 13 & 4.03 \\
\hline $\mathrm{Sr}$ & 75 & 290 & 205 & 147 & 77.6 & 131 & 56.3 \\
\hline Y & 10 & 5 & -5.17 & 8 & -1.69 & 10.0 & 0.03 \\
\hline $\mathrm{Zr}$ & 17 & 27 & 9.10 & 27 & 11.0 & 19.0 & 2.05 \\
\hline $\mathrm{Nb}$ & 5 & 6 & 0.80 & 6 & 1.23 & 6.0 & 1.02 \\
\hline $\mathrm{Ba}$ & 39 & 463 & 408 & 36 & -1.62 & 41 & 2.11 \\
\hline S.G. & 3.1 & 2.7 & & 2.9 & & 2.8 & \\
\hline $\mathrm{Fv}$ & & 1.1 & & 1.1 & & 1.10 & \\
\hline
\end{tabular}

been calculated based on tetrahedral aluminum $\left(\mathrm{Al}^{\mathrm{IV}}\right)$ apfu/14 oxygen using the empirical equation of Cathelineau (1988). The overall temperature range from 218 to $411^{\circ} \mathrm{C}$ with modes at $250^{\circ} \mathrm{C}, 340^{\circ} \mathrm{C}$, and $380^{\circ} \mathrm{C}$. Chlorite I is crystallized in the temperature range of 300 to $411^{\circ} \mathrm{C}$, whereas chlorite II crystallized at 218 to $309^{\circ} \mathrm{C}$. Biotite Biotite is commonly associated with the hydrothermal alteration zones that contain high $\mathrm{K}_{2} \mathrm{O}$ and crystallized at the expense of chlorite and muscovite. Pseudomorphs of biotite after chlorite are very common. Biotite crystallizing along brittle fractures that cut across pyroxenes, hornblende, and tremolite-actinolite are frequently observed. Electron microprobe analyses of biotite (Table $3 b)$ display $\mathrm{Fe} /(\mathrm{Fe}+\mathrm{Mg})$ ratios that range from 0.31 to 0.53 . The $\mathrm{Al}^{\mathrm{IV}}$ and $\mathrm{Al}^{\mathrm{VI}}$ contents of biotite vary from 2.30 to 2.63 atom apfu and 0.41 to 1.147 apfu respectively. Two groups of biotite have been distinguished based on the $\mathrm{Al}^{\mathrm{VI}}, \mathrm{Fe}$, and $\mathrm{Mg}$ contents. Paragenetically older biotite (biotite I) has low $\mathrm{Al}^{\mathrm{VI}}$ but high $\mathrm{Fe}$ abundance as compared to younger biotite (biotite II; Fig. 8b). Biotite is associated with pyrite II porphyroblasts. There is strong negative correlation between $\mathrm{Al}^{\mathrm{VI}}$ and divalent cations (Fe, Mn, and $\mathrm{Mg}$ ), suggesting simultaneous sub- stitution of $\mathrm{Al}^{\mathrm{VI}}$ for $\mathrm{Fe}, \mathrm{Mn}$, and $\mathrm{Mg}$ and $\mathrm{Al}^{\mathrm{IV}}$ for $\mathrm{Si}$. The Fe deficiency during biotite II formation is probably due to crystallization of pyrite II. Ti contents of biotite vary from 0.06 to 0.50 apfu and show strong positive correlation with $\mathrm{Fe} /(\mathrm{Fe}+\mathrm{Mg})$ ratios suggesting coupled substitution of $2 \mathrm{Al}^{3+}$ for $\mathrm{Ti}^{4+}$ and $\mathrm{Fe}^{2+}$ in the biotite structure. Amphiboles Amphiboles dominantly occur in epidoteamphibole-chlorite schist. Electron microprobe analyses of samples of amphiboles show clear zoning, ferroactinolite core and ferro-hornblende rim. Ferrohornblende without any ferro-actinolite core has also been observed. The ferro-actinolite core has lower abundance of $\mathrm{Na}_{2} \mathrm{O}(0.15$ to 0.60 wt $\%), \mathrm{FeO}\left(<12\right.$ wt \%), $\mathrm{TiO}_{2}(0.01$ to $0.07 \mathrm{wt} \%)$ and lower ratios of $[\mathrm{Fe} /(\mathrm{Fe}+\mathrm{Mg}) ;<0.35]$ and $[\mathrm{Al} /(\mathrm{Al}+\mathrm{Si}) ;<0.10]$, but high $\mathrm{CaO}(>12 \mathrm{wt} \%)$ and $\mathrm{MgO}(>14 \mathrm{wt} \%)$ than the ferro-hornblende (Table 3c). Plot of $\mathrm{Al}^{\mathrm{VI}}$ versus $\mathrm{Si}$ (apfu/23 oxygen) of the ferrohornblende has been used to estimate the pressure of hornblende formation (Fig. 8c). Almost all the samples plot slightly higher than the $5 \mathrm{kbar}$ dividing line between the high- and low pressure (Raase, 1974).

Plagioclase The $\mathrm{Ca}$ and $\mathrm{Na}$ contents of plagioclase vary from 0 to 1.7 and 0.1 to 4.31 (apfu/32 oxygen), respec- 


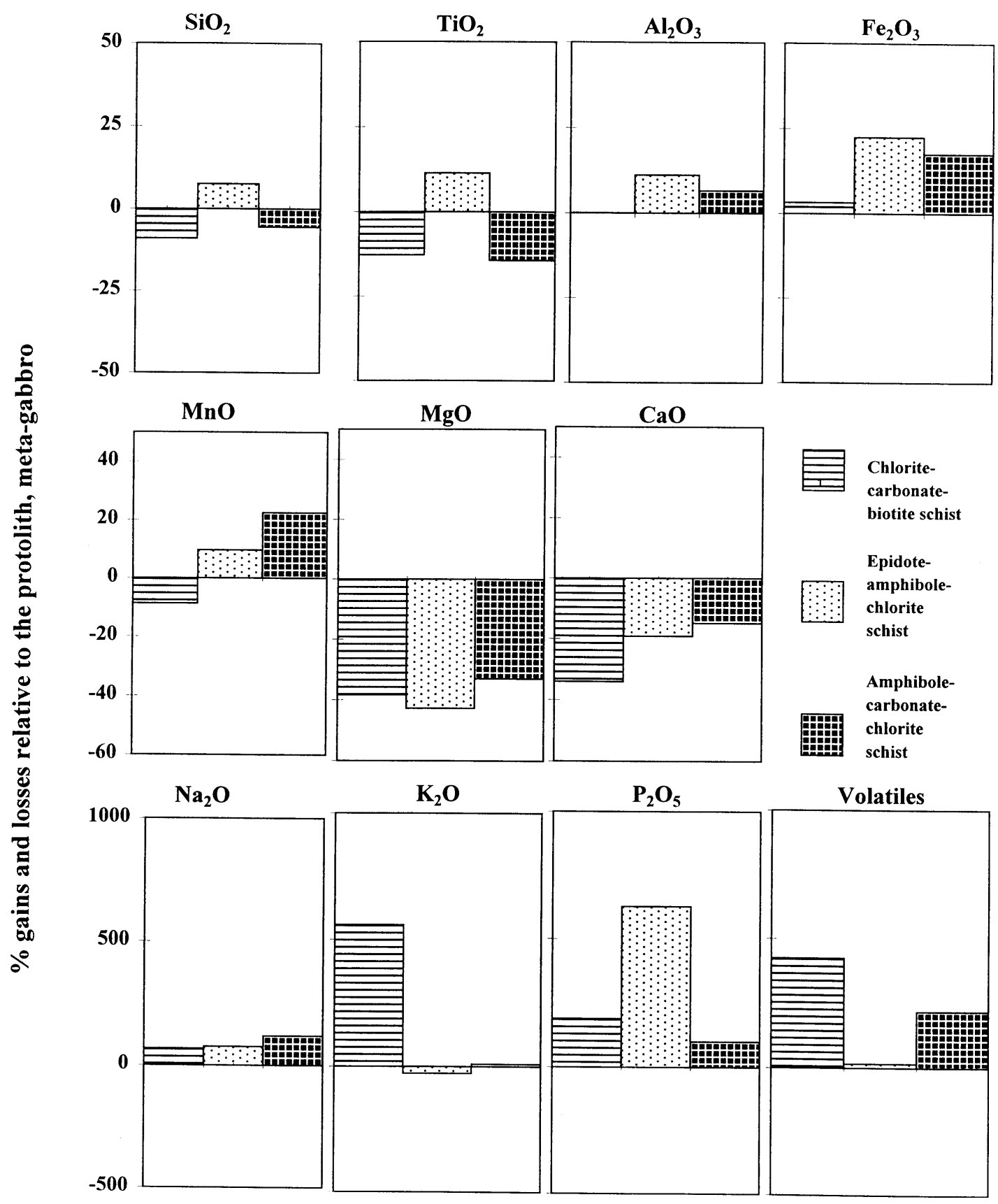

Fig. 9. Gains and losses in the major oxides for the alteration zones relative to that in fresh meta-gabbro (DR-44) in Okote area, using the volume factors 1.1.

tively. The Ca-rich plagioclase (bytownite) in the metagabbro altered, at different degrees of alteration to andesine, oligoclase, and albite. Plagioclase from epidoteamphibole-chlorite schist is in the range of oligoclase to andesine, whereas that in chlorite-carbonate-biotite schist is mainly albite with relicts up to andesine.

Carbonates Two types and generation of carbonate have been distinguished, ankerite and calcite. Textural relationship indicates that calcite formed after ankerite, i.e., ankerite is commonly replaced by calcite. Ankerite contains 6 to $14 \mathrm{wt} \% \mathrm{FeO}, 10$ to $20 \mathrm{wt} \% \mathrm{MgO}$, and 0.3 to $1.25 \mathrm{wt} \% \mathrm{MnO}$. $\mathrm{FeO}$ and $\mathrm{MgO}$ contents of ankerite show strong negative correlation due to substitution of $\mathrm{Fe}^{2+}$ for $\mathrm{Mg}$ and $\mathrm{Mg} / \mathrm{Fe}$ ratio is less than 1. Calcite occurs in veins and in their wall rocks. Calcite consists of less than $2 \mathrm{wt}$ $\% \mathrm{MgO}$, up to $3 \mathrm{wt} \% \mathrm{FeO}$, and 0.23 to $1.85 \mathrm{wt} \% \mathrm{MnO}$. The $\mathrm{MgO}$ and $\mathrm{FeO}$ contents of calcite show positive correlations, indicating $\mathrm{Fe}$ and $\mathrm{Mg}$ substitution for $\mathrm{Ca}$. 

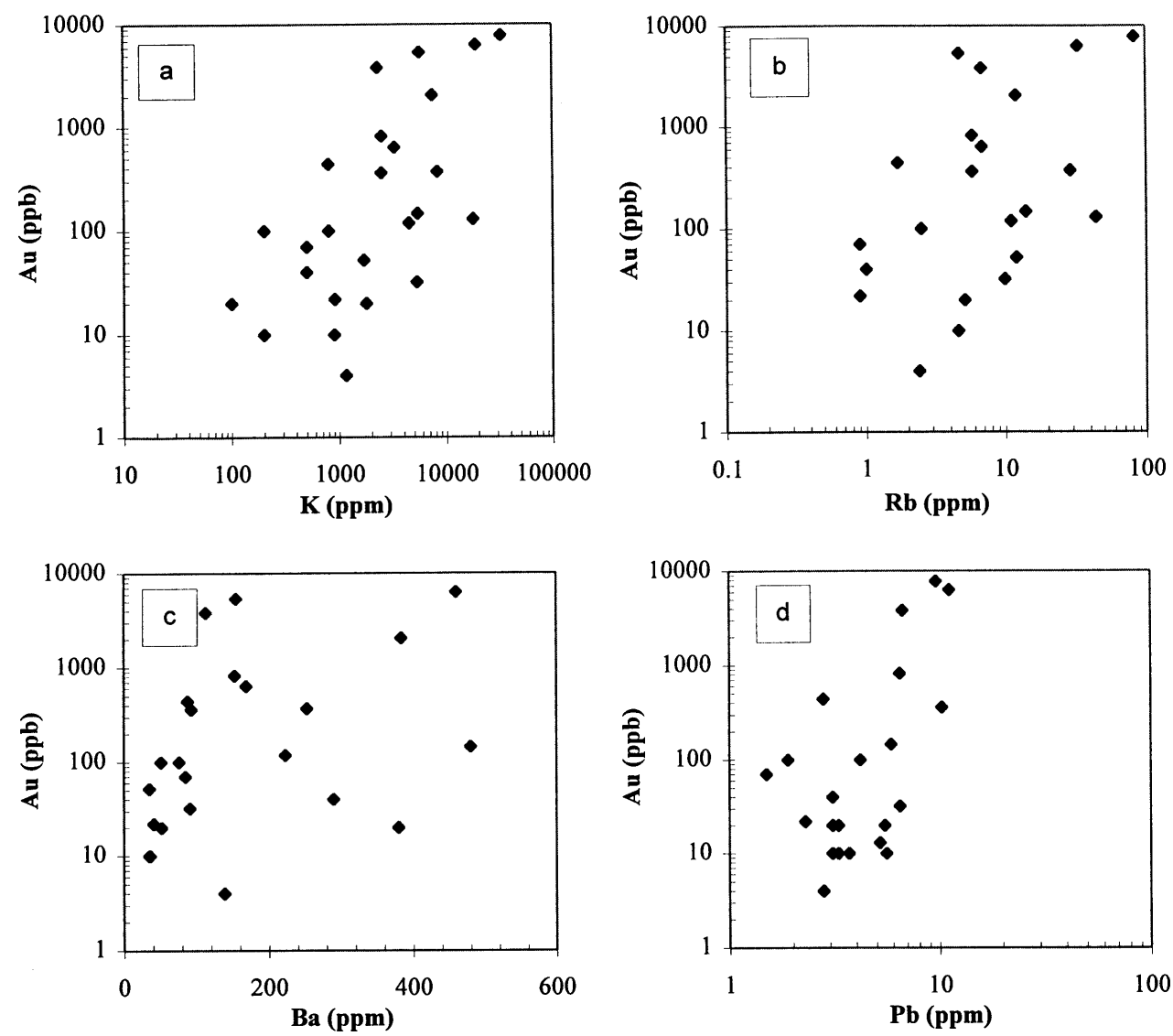

Fig. 10. Diagrams showing strong correlation between the contents of gold and large ion lithophile elements (LILE).

Epidote Epidote is a common mineral in the alteration zones. It varies in grain size from very fine crystals in plagioclase showing saussuritization to very coarsegrained in epidote-amphibolite-chlorite schist. Epidote occurs in the forms of veinlets and in the alteration zones at variable intensity. The electron microprobe analyses of epidote from the gold mineralized part of the Okote area shows clear zoning in which the core is enriched in $\mathrm{Al}$ and $\mathrm{Ca}$ contents and depleted in $\mathrm{Fe}, \mathrm{Mn}^{3+}$, and $\mathrm{Si}$ than the rim. Epidote contains 11 to 31 mole \% pistacite and 0.1 to 0.7 mole $\%$ piemontite. The zoning of epidote suggests variations in fluid composition and at least two stages of hydrothermal infiltration. The older epidote (core with Fe depletion) is associated with magnetite, Ferich amphiboles, and plagioclase. In contrast, epidote with Fe-rich rim is associated with chlorite, calcite, pyrite and biotite. The variation in Fe contents of epidote, therefore, is related to the redox condition of the hydrothermal fluid. Epidote with an aluminum-rich core and iron-rich rim has been correlated to stages of prograde metamorphism that was subsequently followed by a retrograde event (Deer et al., 1985, 1992).

\section{Compositional variation during alteration}

Chemistry of altered rocks in terms of mineralogical changes The main chemical changes chlorite-carbonatebiotite schist are the addition of volatile (LOI), $\mathrm{Fe}_{2} \mathrm{O}_{3}$, $\mathrm{K}_{2} \mathrm{O}, \mathrm{P}_{2} \mathrm{O}_{5}, \mathrm{Ba}, \mathrm{Cu}, \mathrm{Sr}$, and $\mathrm{V}$, and loss of $\mathrm{MgO}, \mathrm{CaO}$, and $\mathrm{SiO}_{2}$ (Table 4; Fig. 9). The addition of the volatile major and trace elements are well correlated with the mineral assemblages observed in the schist. The gain of $\mathrm{K}_{2} \mathrm{O}$ is clearly shown by the occurrences of biotite, K-feldspar, and muscovite. The abundance of alteration minerals, such as chlorite, carbonate, and pyrite indicate the addition of volatile into sheared parent rock. The losses of $\mathrm{MgO}, \mathrm{CaO}$, and $\mathrm{SiO}_{2}$ from the wall rock are coupled with their concentration in the quartz-carbonate-tourmaline veins. The slight depletion of $\mathrm{TiO}_{2}$ can be correlated with the occurrence of anatase in the veinlets.

The epidote-amphibole-chlorite schist gained $\mathrm{Fe}_{2} \mathrm{O}_{3}$, $\mathrm{MnO}, \mathrm{Na}_{2} \mathrm{O}, \mathrm{P}_{2} \mathrm{O}_{5}, \mathrm{SiO}_{2}$, and $\mathrm{TiO}_{2}$ and lost $\mathrm{MgO}, \mathrm{CaO}$, and $\mathrm{K}_{2} \mathrm{O}$ (Table 4). The gains in $\mathrm{Fe}_{2} \mathrm{O}_{3}, \mathrm{MnO}$, and $\mathrm{TiO}_{2}$ content are mainly due to the occurrence of Fe-rich epidote, magnetite, ilmenite, sphene, $\mathrm{TiO}_{2}$-minerals (rutile and anatase), and ilmenite in the schist. The addition of 

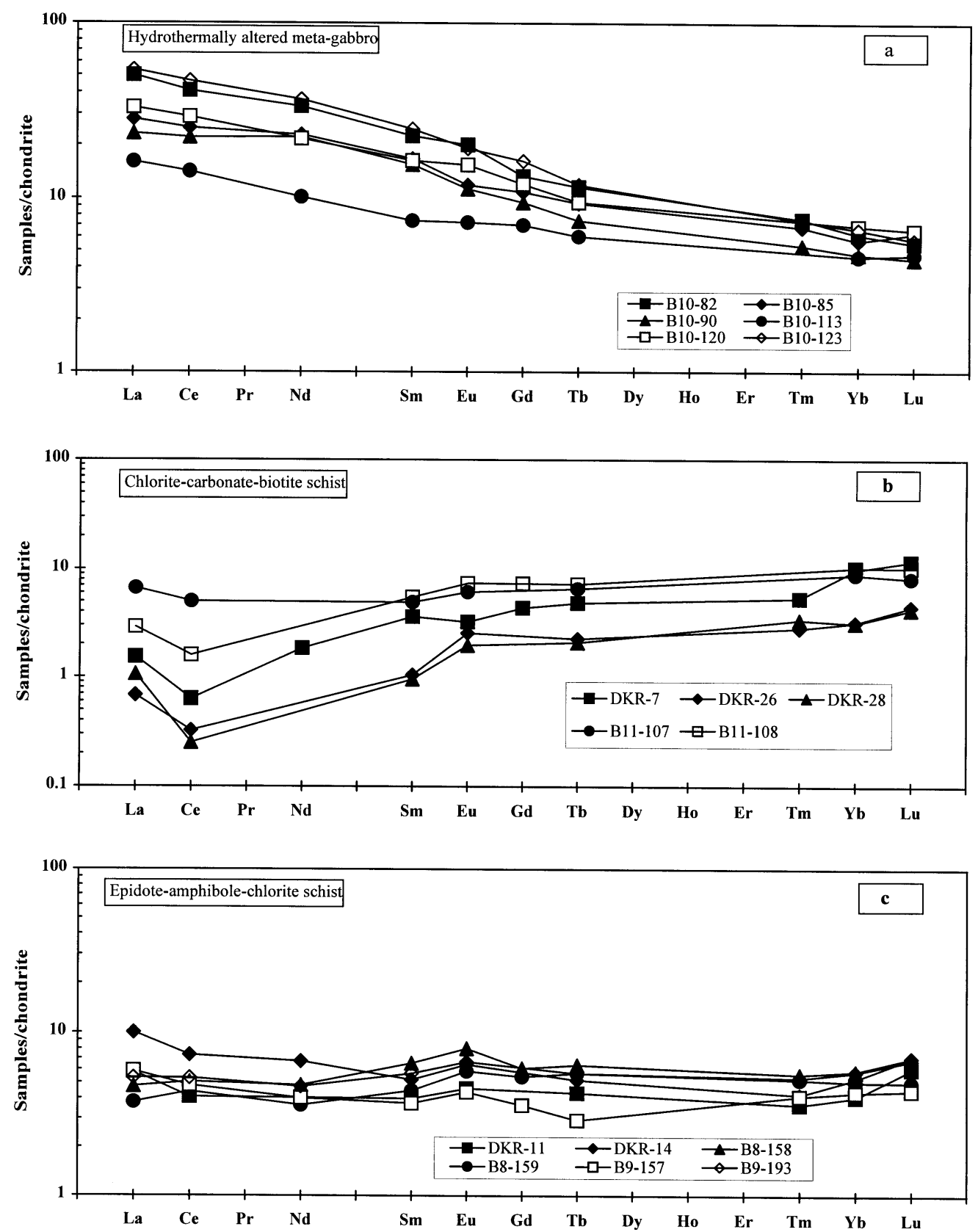

Fig. 11. Chondrite-normalized REE abundance patterns for hydrothermal alteration zones of the Okote area; normalization factors from Taylor and McLennan (1985).

$\mathrm{SiO}_{2}$ is related to minor silicification of the schist. The $\mathrm{MgO}$ and $\mathrm{CaO}$ losses are related to their concentrations in quartz-carbonate veins.

The chemical changes in amphibole-carbonate-chlorite schist are similar to that observed in chlorite-carbonatebiotite schist, except for the absence of $\mathrm{K}$-bearing minerals and a slight enrichment in the $\mathrm{Fe}_{2} \mathrm{O}_{3}, \mathrm{MnO}$, and $\mathrm{Na}_{2} \mathrm{O}$ contents of the schist (Table 4).

Trace element chemistry alteration zones The contents of the large ion lithophile elements (LILE), such as K, $\mathrm{Rb}, \mathrm{Pb}$, and $\mathrm{Ba}$, are strongly correlated with $\mathrm{Au}$ abundance (Fig. 10). Mass balance calculation indicates that these elements are gained in mineralized chloritecarbonate-biotite schist. The LILE-containing metasomatic minerals associated with gold are $\mathrm{K}$ feldspars, muscovite, biotite, and sericite.

Samples from altered and gold mineralized areas show a negative correlation of $\mathrm{SiO}_{2}$ with the abundance of 
volatiles ( $\mathrm{LOI}$ ), $\mathrm{K}, \mathrm{Rb}$, and $\mathrm{Ba}$. The results indicate that metasomatic alteration is involved in introduction of considerable amount of volatile $\left(\mathrm{CO}_{2}, \mathrm{H}_{2} \mathrm{~S}, \mathrm{H}_{2} \mathrm{O}\right), \mathrm{K}_{2} \mathrm{O}, \mathrm{Rb}$, and $\mathrm{Ba}$ into the wall rock, removal of $\mathrm{SiO}_{2}$ from wall rock and its deposition in veins.

Chondrite-normalized rare earth element (REE) patterns of the meta-gabbro boudins in shear zone (hydrothermally altered meta-gabbro; but not sheared metagabbro), chlorite-carbonate-biotite schist, and epidoteamphibole-chlorite schist are shown in Fig. 11. Partially altered meta-gabbro has more total REE than fresh metagabbro and displays a depletion of heavy REE without Eu anomaly. In contrast, fresh meta-gabbro, far-away shear zone, shows enrichments in the heavy REEs relative to light REEs $\left[(\mathrm{La} / \mathrm{Yb})_{\mathrm{N}}=0.09\right.$ to 0.65$]$ and a moderately positive $\mathrm{Eu}$ anomaly $\left[\left(\mathrm{Eu} / \mathrm{Eu}^{*}\right)=1.26\right.$ to 1.99$]$. Chlorite-carbonate-biotite schist shows a significant depletion in $\mathrm{Ce}$, and enrichments of heavy REE without $\mathrm{Eu}$ anomaly. The strong depletion of Ce relative to light REE indicates Ce mobility during this hydrothermal alteration event. The epidote-amphibole-chlorite schist shows a flat REE pattern with a moderate positive Eu anomaly.

\section{FLUID INCLUSION STUDY}

\section{Fluid inclusion petrography}

Clear grains or crystal domains of auriferous quartz veins host almost all the studied fluid inclusions. Fluid inclusion in quartz vein may occur as irregular seemingly random clusters of inclusion types I, II, and III, and irregular clusters of type IV inclusions.

The size of fluid inclusions within auriferous type II quartz veins $\left(\mathrm{qv}_{2}\right)$ range from $5<$ to $23 \mu \mathrm{m}$. and the inclusions have generally ellipsoidal, spheroid, subidiomorphic granular, irregular or negative crystal shapes.

Type I: At room temperature these are two phase $(\mathrm{L}+$ V) inclusions occurring as single inclusions and clusters and are located away from healed microfractures within the milky quartz of gold mineralized veins. These inclusions have irregular shapes with variable proportions of liquid and vapor.

Type II: At room temperature these are variable sized three-phase inclusions occurring as single inclusions in quartz crystals. They show elliptical and irregular shapes with spherical vapor bubbles.

Type III and IV: these inclusions generally are very small in size, negative crystal to elliptical, dark gray in color, and frequently occur in planes and trials.

\section{Fluid inclusion microthermometry}

Inclusions have been classified into four types based on phase composition at room temperature and microthermometric analysis.

Type I, Aqueous fluid inclusions Type I inclusions have
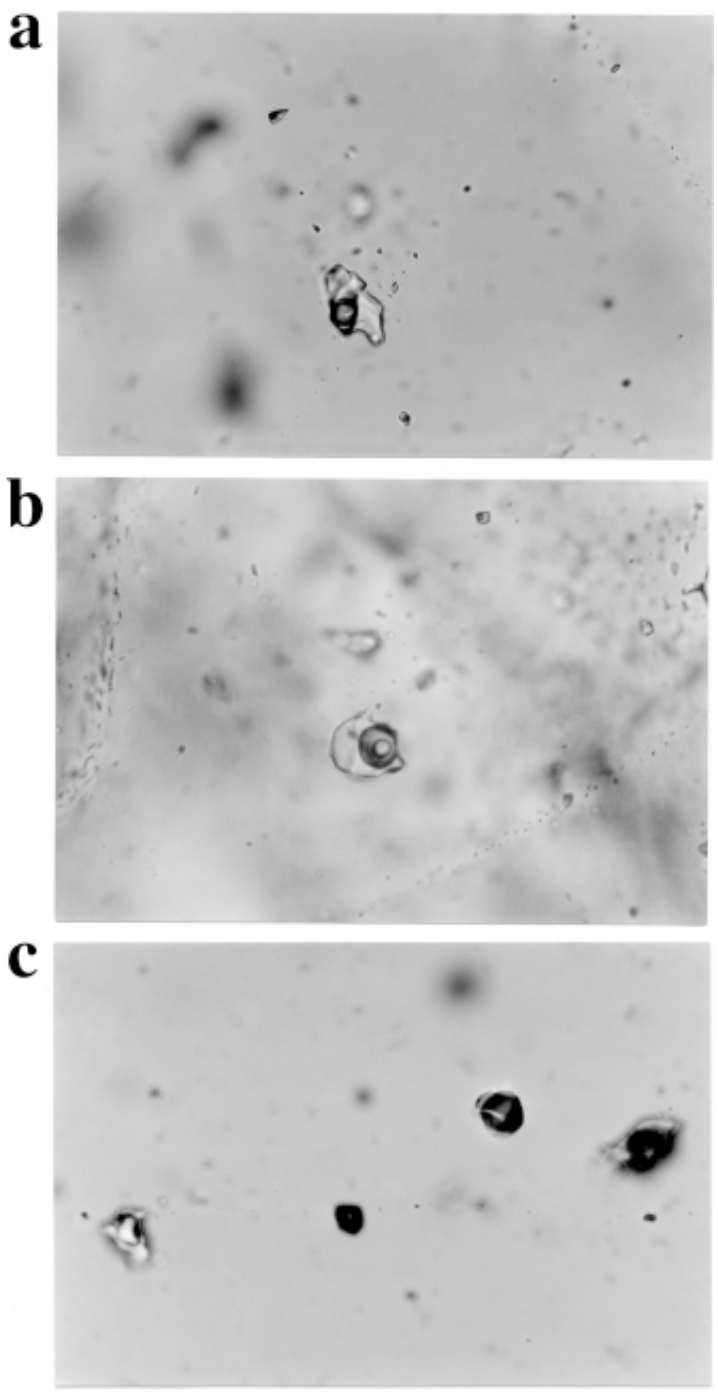

Fig. 12. Auriferous quartz vein hosted fluid inclusions: a) irregular, two phase type I aqueous fluid inclusions; b) spheroidal, type II three phase aqueous-carbonic inclusions; c) negative crystal shape type IV, carbonic fluid inclusions; width of all images is $0.325 \mathrm{~mm} \times 0.22 \mathrm{~mm}$; all were taken under plane polars.

no $\mathrm{CO}_{2}$ and daughter minerals. Type inclusions (Fig. 12a) are the earliest inclusions. Trapping of type I inclusions involve low salinity $\mathrm{H}_{2} \mathrm{O}$ inclusions. Temperatures of homogenization $\left(T_{\mathrm{H}}\right)$, always to the liquid phase, were between 234 and $329^{\circ} \mathrm{C}\left(\right.$ mean $\left.=270^{\circ} \mathrm{C}\right)$. Temperatures of final melting of ice $\left(T \mathrm{~m}_{\text {ice }}\right)$ in type I inclusion range from $-4.1^{\circ} \mathrm{C}$ to $-1.3^{\circ} \mathrm{C}$ indicating salinities of 6.59 to 2.24 wt $\% \mathrm{NaCl}$ equivalents (mean value $4.41 \%$ ). The aqueous type I inclusions have a density range of 0.67 to 0.90 $\mathrm{g} / \mathrm{cm}^{3}$. Temperatures of decrepitation $\left(T_{\mathrm{d}}\right)$ range from 230 to $388^{\circ} \mathrm{C}($ mean $=301)$.

Type II, Three phase aqueous-carbonic inclusions Type 

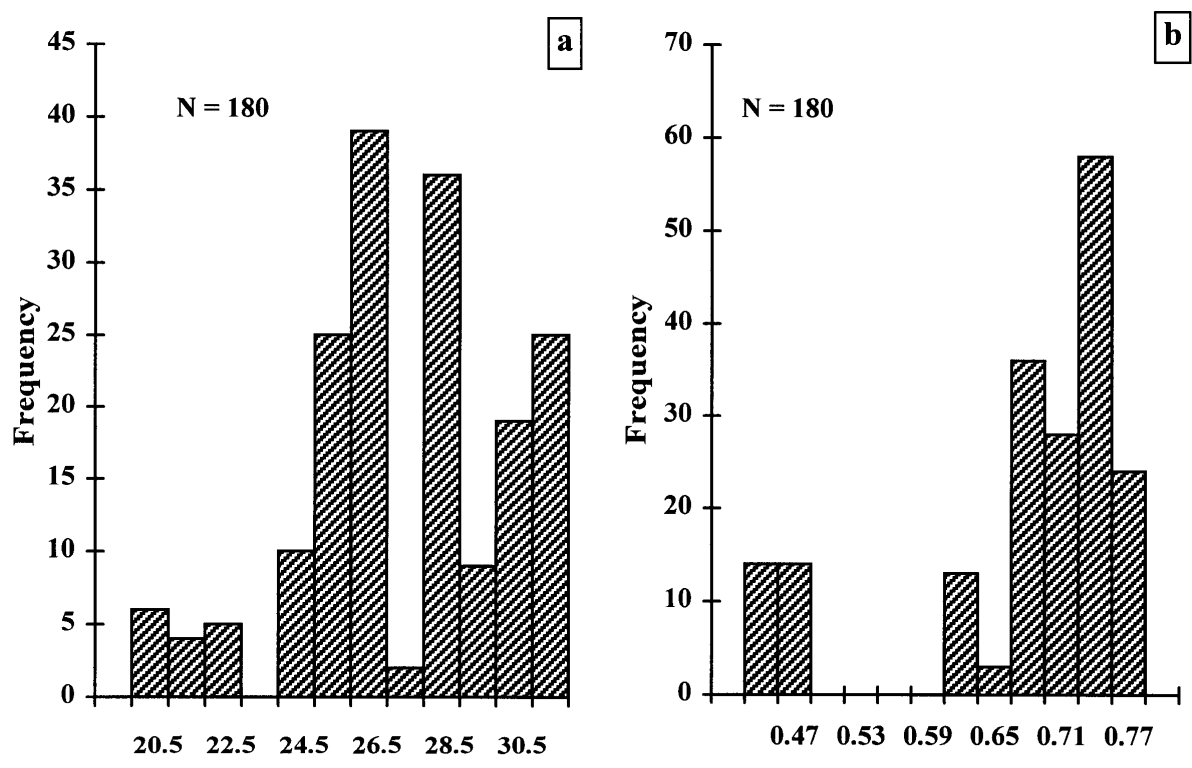

$\mathrm{T}_{\mathrm{H}} \mathrm{CO}_{2}\left({ }^{\circ} \mathrm{C}\right)$

Density of $\mathrm{CO}_{2}$ fluid
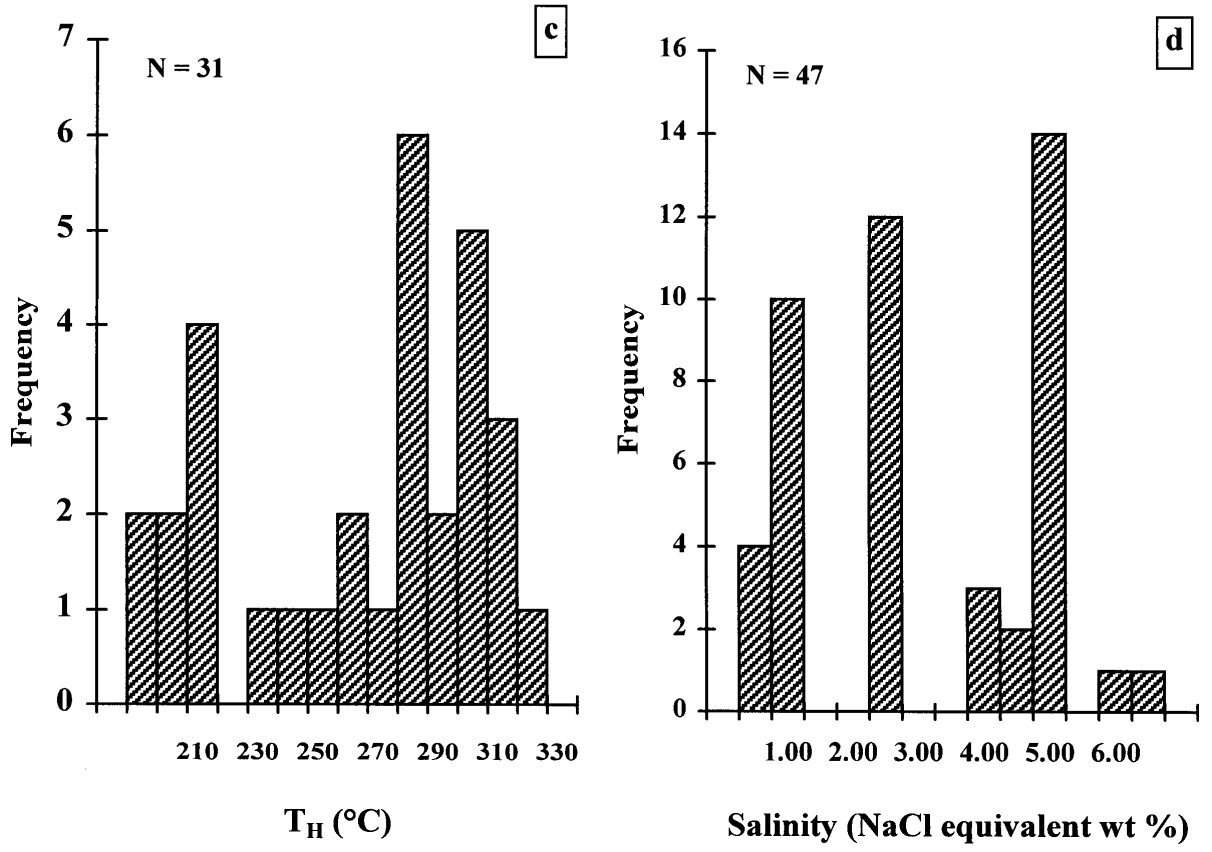

Fig. 13. Frequency (number of analysis) histograms of a) $\mathrm{T}_{\mathrm{H}} \mathrm{CO}_{2}$, b) density of $\mathrm{CO}_{2}$ fluid, c) total homogenization temperature $\left(T_{H}\right)$ and $d$ ) salinity of fluid inclusion in type II quartz veins, Okote area, southern Ethiopia.

II inclusions contain $\mathrm{H}_{2} \mathrm{O}$ liquid, and $\mathrm{CO}_{2}$ liquid and vapor (Fig. 12b). Melting temperatures of solid $\mathrm{CO}_{2}\left(T_{\mathrm{M}} \mathrm{CO}_{2}\right)$ in type II inclusions range from -56 to $-57^{\circ} \mathrm{C}$. Homogenization temperature of the $\mathrm{CO}_{2}$ liquid and vapor to liquid state $\left(T_{\mathrm{H}} \mathrm{CO}_{2}\right)$ range 18.7 to $29^{\circ} \mathrm{C}$ respectively. Type II inclusions have constant clathrate melting temperature $\left(T_{\mathrm{M}}\right.$ Clath $\left.=8.7 \pm 1\right)$ and $T_{\mathrm{H}}$ range from 218 to $345^{\circ} \mathrm{C}$ $\left(\right.$ mean $\left.=284^{\circ} \mathrm{C}\right)$. The deviation of univariant clathrate hydrate melting temperature from that at $+10.1^{\circ} \mathrm{C}$ in the pure $\mathrm{CO}_{2}-\mathrm{H}_{2} \mathrm{O}$ system may be due to the presence of salts (e.g., $\mathrm{NaCl}$ ). Interpreted in terms of ternary $\mathrm{H}_{2} \mathrm{O}-\mathrm{NaCl}$ $\mathrm{CO}_{2}$ compositions, the clathrate hydrate melting temperatures recorded below $+10.1^{\circ} \mathrm{C}$ correspond to salinities between 0.2 and 8.3 wt $\% \mathrm{NaCl}$ equivalent (Collins, 1979). Accordingly, the salinity of the type II fluid inclusions is $2.5 \mathrm{wt} \% \mathrm{NaCl}$ equivalent. A large number of 


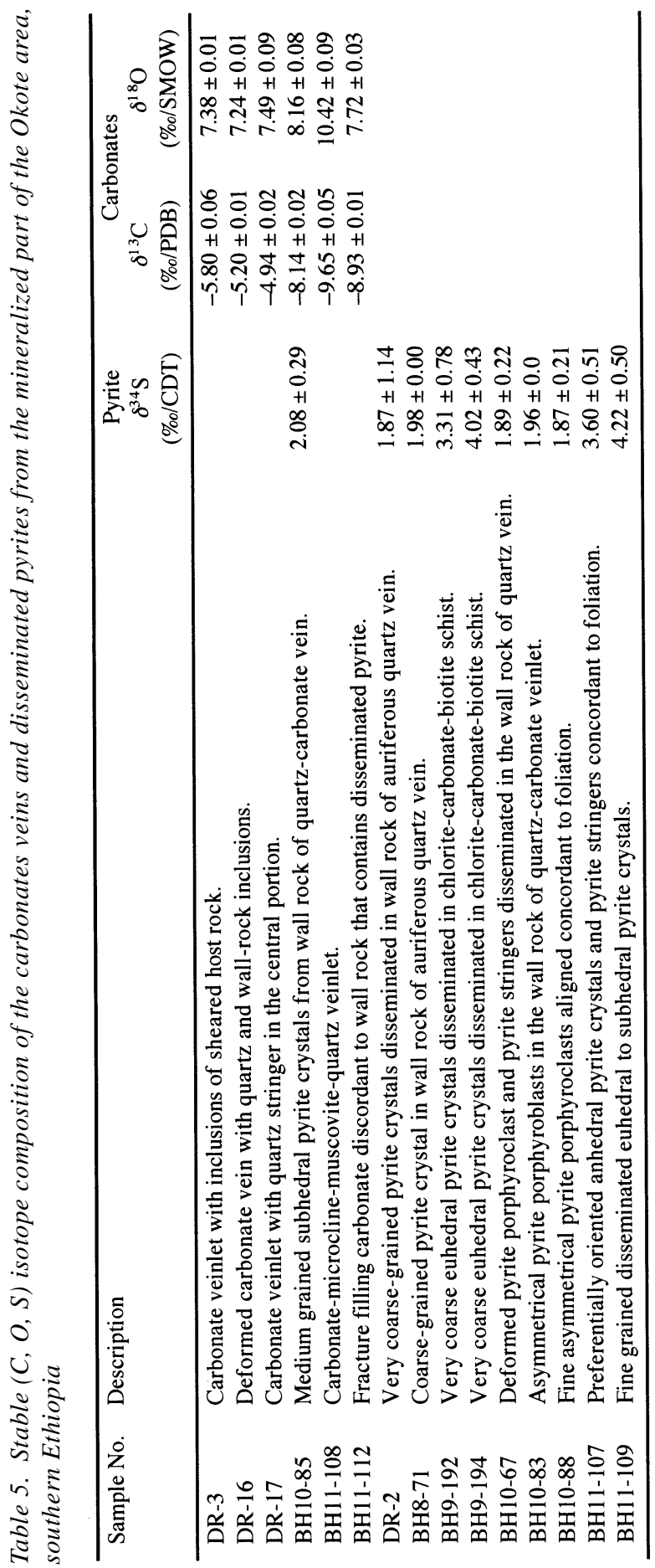

inclusions decrepitate before and immediately after homogenization demonstrating decrepitation occurred at temperatures very close to total homogenization. Temperatures of decrepitation $\left(T_{\mathrm{d}}\right)$ range from $220^{\circ} \mathrm{C}$ to $343^{\circ} \mathrm{C}$ (mean $\left.=263^{\circ} \mathrm{C}\right)$. Density of fluid ranges from 0.68 to 0.79 $\mathrm{g} / \mathrm{cm}^{3}$ and is in good correlation with the degree of filling (60 to $75 \%)$.

Type III, Two-phase pseudosecondary vapor-rich inclusions Type III inclusions consist of $\mathrm{CO}_{2}$-liquid, $\mathrm{CO}_{2}$ vapor and $\mathrm{H}_{2} \mathrm{O}$ vapor in which the $\mathrm{CO}_{2}$ abundance predominant over that of $\mathrm{H}_{2} \mathrm{O}$ (Fig. 12c). These inclusions have moderate density $\left(0.62\right.$ to $\left.0.79 \mathrm{~g} / \mathrm{cm}^{3}\right)$ and low value of $T_{\mathrm{H}}\left(136^{\circ} \mathrm{C}\right)$. The $T_{\mathrm{M}} \mathrm{CO}_{2}$ and $T_{\mathrm{H}} \mathrm{CO}_{2}$ range from $-56^{\circ} \mathrm{C}$ to $-58^{\circ} \mathrm{C}$ and from $18.5^{\circ} \mathrm{C}$ to $29.3^{\circ} \mathrm{C}$, respectively.

Type IV, Carbonic fluid primary inclusions Type IV inclusions contain $\mathrm{CO}_{2}$ liquid and vapor (Fig. 12c) with $T_{\mathrm{M}} \mathrm{CO}_{2}$ range from -58.7 to $-54^{\circ} \mathrm{C}$, and low density $(0.38$ to $0.47 \mathrm{~g} / \mathrm{cm}^{3}$ ). The low-temperature behavior of the type IV inclusions indicate that the minor additional component is $\mathrm{CH}_{4}$. The $T_{\mathrm{H}} \mathrm{CO}_{2}$ to vapor phase range from 30 to $31.6^{\circ} \mathrm{C}$.

Frequency histogram plots of $T_{\mathrm{H}} \mathrm{CO}_{2}$, density of $\mathrm{CO}_{2}$ fluid, total homogenization temperature $\left(T_{\mathrm{H}}\right)$ and salinity of the fluid inclusion (Fig. 13) display three modes indicating the variation of the fluid composition during fluid entrapment.

\section{Stable isotopes}

The analytical results of carbon, sulfur, and oxygen isotopic data of carbonate veins and pyrite disseminated in altered wall rock are shown in Table 5. The $\delta^{18} \mathrm{O}$ value of calcite range from +7.24 to $+10.42 \%$ o $($ mean $=+8.1 \pm$ $1.19 \%$ ). Samples with high $\delta^{18} \mathrm{O}$ value contain magnetite, ilmenite, and rutile indicating variation redox condition. The $\delta^{13} \mathrm{C}$ of carbonate range from -9.65 and $-4.94 \%$, (mean $=-7.1 \pm 2.05 \%$ ). The $\delta^{18} \mathrm{O}$ and $\delta^{13} \mathrm{C}$ values of calcite are negative correlated. The $\delta^{34} \mathrm{~S}$ values of pyrite vary within a narrow range between 1.87 and $4.22 \%$ (mean $2.68 \pm 0.98 \%$ ) .

\section{DISCUSSION}

Ore genesis

Nature of ore fluids The nature of ore fluid has been derived from mineral paragenesis and fluid inclusion studies of auriferous quartz veins. The mineral assemblage and their chemistry indicate at least three paragenetic stages: early stage of ocean floor and/or regional metamorphism of the protolith (gabbro), followed by moderate to high temperature hydrothermal alteration and formation of epidote-amphibole-chlorite schist, and final stage of intense carbonate alteration. The mineral assemblage in the epidote-amphibole-chlorite schist (e.g., amphibole, chlorite, epidote, magnetite, and ilmenite) 
suggests oxidizing, aqueous, near neutral $\mathrm{pH}$, moderate temperature hydrothermal fluids interacted with mafic wall rock under conditions of low fluid/rock ratio.

Fluid inclusion studies of auriferous quartz veins have shown that the fluids were $\mathrm{H}_{2} \mathrm{O}-\mathrm{CO}_{2}$, low salinity (generally less than $6 \mathrm{wt} \% \mathrm{NaCl}$ equivalent) and and have low to moderate density. The fluid was near neutral and reducing. The minimum gold deposition temperatures range from 220 to $345^{\circ} \mathrm{C}$ as determined from homogenization temperatures of fluid inclusions. The pressure of the fluid was less than $2 \mathrm{kbar}$ as determined from fluid inclusion data and mineral paragenesis. There is no significant methane present in the fluid, suggesting that the fluid was not in contact with carbonaceous sediments. The $\mathrm{CO}_{2} / \mathrm{H}_{2} \mathrm{O}$ ratios increase with decreasing of temperature and from earliest to the most recent stages of fluid entrapment. Variable degree of phase separation is interpreted due to the occurrences of earliest stage aqueous fluid, followed by intermediate stages three phase aqueous-carbonic inclusions and two-phase pseudosecondary vapor-rich inclusions, and a final stage of carbonic fluid primary inclusions.

Source of fluid and gold Fluid inclusions in auriferous quartz veins of the Okote area are of low salinity, moderate density, $\mathrm{H}_{2} \mathrm{O}-\mathrm{CO}_{2}$ in composition, and moderate in temperature. These types of fluids, unlike those of basinal barins, porphyry $\mathrm{Cu}-\mathrm{Au}$ or epithermal gold systems, are almost comparable in composition with metamorphic fluids from amphibolite facies terranes (Kerrich and Fyfe, 1981; Schenk et al., 1990). They can also be produced by $\mathrm{CO}_{2}$ saturation in $\mathrm{H}_{2} \mathrm{O}-\mathrm{CO}_{2}$ bearing silicate magma or possibly mantle degassing and subsequent crustal degassing (Groves and Foster, 1991; Turret, 1981; Ohmoto and Rye, 1979; Taylor, 1986).

In an attempt to resolve the source of gold and fluid themselves, stable isotope, fluid inclusion and incompatible ilmenite ratios studies have been carried out.

The carbon isotope composition of calcite associated with gold mineralization indicates a $\delta^{13} \mathrm{C}$ value for $\mathrm{CO}_{2}$ in the ore fluid of -3 to $-7.83 \%$ o. These values for broadly are compatible with juvenile origin for the carbon. Many authors suggest that the $\delta^{13} \mathrm{C}$ data in the above range are compatible with magmatic origin for $\mathrm{CO}_{2}$ (Deines and Gold, 1973; Deines, 1980), but others have suggested that the $\delta^{13} \mathrm{C}$ data are compatible with metamorphic dissolution of a mantle-derived carbonation zone along the regional shear zone that also host gold mineralization. The data preclude a source purely derived by metamorphic devolatilization of carbonate related to sea floor alteration of volcanic rocks in greenstone succession. The $\delta^{34} \mathrm{~S}$ values of pyrite range from 1.87 to 4.22 and calculated $\delta^{34} \mathrm{~S}$ of the fluid cluster in between 0.65 to $3 \%$ sulfur. Within these composition range the source could be equally derived directly from a magmatic source or via metamorphic devolatilization or dissolution of dominantly volcanic terranes, such as greenstone belts. The $\delta^{18} \mathrm{O}$ of calcite range from 7.24 to $10.42 \%$ SMOW. These $\delta^{18} \mathrm{O}$ are consistent with a metamorphic fluid source.

Incompatible element ratios (e.g., $\mathrm{K} / \mathrm{Rb}$ ranging fromto-) suggest less fractionation than that normally recorded from alteration zones of generally accepted magmatic-fluid mineral deposits.

The fluid inclusion, stable isotope data, and incompatible element association and ratios indicate the predominance of a metamorphic source over a magmatic source.

Transport and deposition of gold The nature of ore element association and an intimate association of gold with pyrite and chalcopyrite suggest that gold was transported as reduced sulfur complexes (e.g., see Phillips and Groves, 1983). This interpretation is consistent with available experimental data of Seward (1973). The narrow high strain shear zone that cuts the mafic rocks of the Okote area appears ideal for the strong focusing of the ore fluids required to produce the observed gold mineralization.

Gold deposition is related to changes in fluid chemistry that may result from a variety of processes, including fluid mixing, fluid-wall rock interactions, and phase separation. Fluid wall rock interaction is the main cause of gold mineralization. The mineral assemblages associated with gold mineralization indicate at least two major episodes of hydrothermal alteration that are associated with shearing. The earliest stage of aqueous fluid interaction with the host rock has resulted in the mineral assemblages observed in the epidote-amphibole-chlorite schist. This alteration was followed by more intense shearing and infiltration of low salinity, $\mathrm{CO}_{2}$ rich, auriferous hydrothermal fluid that replaced most of older alteration minerals and deposited the mineral assemblage observed in the chlorite-carbonate schist. The overall reaction during the ore stage alteration consists essentially of a) aqueous potassium $\left(\mathrm{K}^{+}\right)$to form $\mathrm{K}$-feldspar, biotite, sericite, and muscovite, b) sulfidation of elemental iron to form pyrite, chalcopyrite, pyrite, and c) carbonation and hydrolysis of rock to form carbonates, chlorite, epidote-group minerals, and albite. The carbonation and hydration reaction liberated $\mathrm{SiO}_{2}, \mathrm{Mg}, \mathrm{Fe}$, and $\mathrm{Ca}$ from ferromagnesian minerals and subsequently deposited them in fractures in the form of quartz-carbonate veins. With decreasing water/rock ratio and increasing distance from vein margin into the wall rock, the alteration assemblages evolved by addition of minerals in the following order: quartz, carbonates, albite, K-feldspar, pyrite, chlorite, biotite, epidote-group, magnetite, tremolite, and parent rock minerals. In conclusion, the interaction of hydrothermal fluid with the ultramafic-mafic rocks along the shear zones was responsible for the gold-pyrite mineralization at the Okote area. 


\section{Conclusions}

Stable isotopic data, regional metamorphic setting, spatial association of gold with greenschist, and lack of gold bearing high grade metamorphic rocks (e.g., gneisses) indicate that the source of the hydrothermal fluid was dominantly metamorphic dehydration and subordinate magmatic fluid.

Primary fluid inclusion data from auriferous quartz vein $\mathrm{qv}_{2}$ show homogenization temperatures in the range of $218^{\circ} \mathrm{C}$ to $345^{\circ} \mathrm{C}$. The late stage mineralizing fluid is characterized by low salinity, higher $\mathrm{CO}_{2}$ content as compared to early stage aqueous phase fluid, with salinity ranging from 2.24 to $6.59 \mathrm{wt} \% \mathrm{NaCl}$ equivalent.

The strong correlation between the abundance of gold and contents of LIL elements also suggests metamorphic dehydration and decarbonation as the main source of the hydrothermal fluid.

Field observations of alteration zones and shear structures, as well as petrographic and geochemical data, provide evidence for pervasive fluid flow in shear zones and complex metasomatic alteration. The hydrothermal fluids, containing $\mathrm{H}_{2} \mathrm{O}, \mathrm{H}_{2} \mathrm{~S}, \mathrm{CO}_{2}, \mathrm{~B}, \mathrm{Au}$, and LIL elements, were focused along the narrow shear zones and reacted with the mafic-ultramafic rocks. The fluid-wall rock interactions were the primary cause for the gold deposition and the intensive hydrothermal alteration.

The association of pyrite, carbonate, K-feldspar, and micas in the wall rock of quartz-carbonate-tourmaline veins indicates that these minerals are good mineralogical indicators for gold mineralization in the Okote area.

Acknowledgments - This work is part of a Ph.D. project by the senior author funded by the Austrian Academic Exchange Service (Österreichischer Akademischer Austauschdienst, ÖAD). Laboratory expenses were covered by the Austrian Science Foundation (Y58-GEO; C.K.). The authors also thank the National Mining Corporation, Dawa-Digati gold exploration project, for admittance to their project area, and for providing support during the field work to D.J.D., who also acknowledges the project geologists in general, and Shiferaw Demisse, Tesfaye Tadese, Yohanis Edossa, and Aknaw Adugna in particular, for their helpful discussions. The authors would like also to thank Jason Newton (University of Vienna) for help with analyzing the stable isotope compositions. We further thank P. Spindler and H. Fröschl (Arsenal, Vienna) for help with ICP-MS analyses, Michael Götnoizinger (University of Vienna) for technical assistance with the fluid inclusion analyses. We are grateful to W. U. Reimold and an anonymous colleague for comments on an earlier version of this manuscript.

\section{REFERENCES}

Berhe, S. M. (1990) Ophiolite in northeast and east Africa: implication for Proterozoic crustal growth. Journal Geological Society London 147, 41-57.
Billay, A. Y., Kisters, A. F. M., Meyer, F. M. and Schneider, J. (1997) The geology of Lega Dembi gold deposit, southern Ethiopia: implication for Pan-African gold exploration. Mineralium Deposita 32, 491-504.

Bodnar, R. J. (1993) Revised equation and table for determining the freezing point depression of $\mathrm{H}_{2} \mathrm{O}-\mathrm{NaCl}$ solution. Geochimica Cosmochimica Acta 60, 683-684.

Cathelineau, M. (1988) Cation site occupancy in chlorites and illites as a function of temperature. Clay Minerals 23, 471485.

Collins, P. L. F. (1979) Gas hydrates in $\mathrm{CO}_{2}$-bearing fluid inclusions and the use of freezing data for the estimation of salinity. Economic Geology 74, 1435-1444.

Deer, T. G., Hockes, A. H. and Zussman, M. M. (1985) An Introduction to Mineralogy. Academic Press, London, 307 pp.

Deer, W. A., Howie, R. A. and Zussman, J. (1992) An Introduction to the Rock Forming Minerals. 2nd ed., Longman Group Ltd., Hong Kong, 696 pp.

Deines, P. (1980) The carbon isotopic composition of diamonds, relation to diamond shape, colors, occurrence, and vapor composition. Geochimica Cosmochimica Acta 44, 943-961.

Deines, P. and Gold, D. P. (1973) The carbon isotopic composition of carbonatites and kimberlite, carbonates and their bearing on the composition of deep-seated carbon. Geochimica Cosmochimica Acta 37, 1707-1733.

Deksissa, D. J. (1996) Preliminary report on the geological and geochemical exploration for gold and base metals at Okote area, southern Ethiopia. Unpubl. Report, National Mining Corporation, Dawa-Digati Gold Exploration Project, Addis Ababa, Ethiopia, 21 pp.

Foster, M. D. (1962) Interpretation and a classification of the chlorite. U.S. Geological Survey Professional Paper 414A, $1-33$.

Gresens, R. L. (1967) Composition-volume relation of metasomatism. Chemical Geology 2, 47-65.

Groves, D. I. and Foster, R. P. (1991) Archean lode gold deposits. Gold Metallogeny and Exploration (Foster, R. P., ed.), 63-103, Blackie, London.

Hoefs, J. (1997) Stable Isotope Geochemistry. Springer-Verlag, Berlin, $201 \mathrm{pp}$.

Kazmin, V. (1972) Geology of Ethiopia (explanatory note to geological map of Ethiopia 1:2000,000). Report, Ministry of Mines, Geological Survey of Ethiopia, Addis Ababa, Ethiopia, $211 \mathrm{pp}$.

Kerrich, R. and Fyfe, W. S. (1981) The gold and carbonate association: The source of $\mathrm{CO}_{2}$ and $\mathrm{CO}_{2}$ fixation reaction in Archean lode deposit. Chemical Geology 33, 265-294.

Koeberl, C. (1993) Instrumental neutron activation analysis of geochemical and cosmochemical samples: a fast and reliable method for small sample analysis. Journal Radioanalytical Nuclear Chemistry 168, 47-60.

Mechessa, A. (1996) Geochemistry, geochronology, and genesis of the Lega Dambi gold deposit, in the Adola gold field of southern Ethiopia. Ph.D. dissertation, University of Vienna, Vienna, Austria, 168 pp.

Mohammed, B. H. (1999) The geology, structure, and geochemistry of the crystalline rocks of the Moyale area, southern Ethiopia: implications for the tectogenesis of the Precambrian basement. Tübinger Geowissenschaftliche 
Arbeiten A50, 102 pp.

Morrison, J., Fallick, T. and Leosson, M. (1996) $\delta^{34}$ S measurement of standards from several laboratories by continuous flow isotope ratio mass spectrometry (CF-IRMS). Technical Note 306, Micromass UK Limited, U.K.

Ohmoto, H. and Rye, R. O. (1979) Isotopes of sulfur and carbon. Geochemistry of Hydrothermal Ore Deposit (Barnes, H. L., ed.), 509-567, John Wiley, New York.

Phillips, G. N. and Groves, D. I. (1983) The nature of Archean gold bearing fluids as deduced from gold deposits of western Australia. Journal Geological Society Australia 30, 2539.

Pirajno, F. (1992) Hydrothermal Deposits: Principles and Fundamental Concepts for Exploration Geologist. SpringerVerlag, Berlin, 709 pp.

Pouchou, J. L. and Pichoir, F. (1991) Quantitative analysis of homogeneous or stratified micro-volumes applying the model "PAP". Electron Probe Quantitation (Heinrich, K. F. J. and Newbury, D. E., eds.), 31-75, Plenum Press, New York.

Raase, P. (1974) Al and Ti contents of hornblende, indicator of pressure and temperature of regional metamorphism. Contribution Mineralogy Petrology 45, 231-236.

Reimold, W. U., Koeberl, C. and Bishop, J. (1994) Roter Kamm Crater, Namibia: Geochemistry of basement rocks and breccias. Geochimica Cosmochimica Acta 58, 2689-2710.

Roedder, E. (1984) Fluid Inclusions. Reviews in Mineralogy 12, 644 pp., Mineral Society of America, NewYork.

Schenk, P., Holl, R., Ivanova, G. F., Naumov, V. B. and Kopneva, I. A. (1990) Fluid inclusion studies of the Felbertal scheelite deposit. Geologische. Rundschau 79, 451-466.

Seward, T. M. (1973) Thio-complexes of gold and transport of gold in hydrothermal solution. Geochimica Cosmochimica Acta 57, 379-399.

Taylor, B. E. (1986) Magmatic volatile: isotopic variation of $\mathrm{C}, \mathrm{H}$, and S. Stable Isotopes in High Temperature Geological Processes (Valley, J. W., Taylor, H. P., Jr. and O'Neil, J. R., eds.), 185-219, Mineralogical Society of America, New
York.

Taylor, S. R. and McLennan, S. M. (1985) The Continental Crust: Its Composition and Evolution. Blackwell, Oxford, $312 \mathrm{pp}$.

Teferi, B. and Zhbanove, E. P. (1991) Geological prospecting and exploration for primary gold and other minerals in Ageremariam, Arero and Bulbul areas, southern Ethiopia. Unpubl. Report, Ethiopian Institute of Geological Surveys, Addis Ababa, Ethiopia, 150 pp.

Tesfaye, T., Yared, D. and Getnet, A. (1996) Final report for the first year of initial gold exploration period. Unpubl. Report, National Mining Corporation, Dawa-Digati Gold Exploration Project, Addis Ababa, Ethiopia, 75 pp.

Tesfaye, T., Hundie, B., Aknaw, A., Henok, D., Yonatan, A., Yared, D., Getnet, A. and Mustefa, S. (1997) Second quarter report on the exploration in Okote-Kereri sub-project area. Unpubl. Report, National Mining Corporation, DawaDigati Gold Exploration Project, Addis Ababa, Ethiopia, 50 pp.

Turret, J. (1981) Fluid inclusion in high-grade metamorphic rocks. Mineralogical Association Canada 6 (Hollister, L. S. and Crawford, M. L., eds.), 182-208.

Vail, J. R. (1987) Late Proterozoic tectonic terranes in the Arabo-Nubian Shield and their characteristic mineralization. Geological Journal Winter Them. Iss. 22, 161-174.

Woldehaimanot, B. and Behrmann, J. H. (1995) A study of metabasite and metagranite chemistry in the Adola region (south Ethiopia): Implication for the evolution of the East African Orogen. Journal African Earth Sciences 21, 459476.

Worku, H. (1996) Structural control and metamorphic setting of the shear zone-related Au vein mineralization of the Adola Belt (southern Ethiopia) and its tectono-genetic development. Journal African Earth Sciences 23, 383-409.

Worku, H. and Schandelmeier, H. (1996) Tectonic evolution of the Neoproterozoic Adola Belt of southern Ethiopia: evidence for a Wilson Cycle process and implication for oblique plate collision. Precambrian Research 77, 179-210. 